Check for updates

Cite this: RSC Adv., 2018, 8, 508

Received 18th September 2017 Accepted 17th November 2017

DOI: $10.1039 / c 7 r a 10353 k$

rsc.li/rsc-advances

\section{Biochar production and applications in soil fertility and carbon sequestration - a sustainable solution to crop-residue burning in India $\uparrow$}

\author{
Dinesh Mohan, (D) *a Kumar Abhishek, ${ }^{a}$ Ankur Sarswat, ${ }^{a}$ Manvendra Patel, (D) ${ }^{a}$ \\ Prachi Singh ${ }^{a}$ and Charles U. Pittman Jrb
}

\begin{abstract}
A sustainable solution to biomass burning by converting agricultural residues into biochar was provided. Biochar application was investigated to improve soil fertility, sequester carbon, and increase crop production. Rice husk (RHBC) and corn stover (CSBC) biochars were obtained by slow pyrolysis at $650^{\circ}$ and $550{ }^{\circ} \mathrm{C}$, respectively. RHBC and CSBC were characterized (SEM, SEM-EDX, TEM, FTIR, XRD, elemental analyses, and $\mathrm{S}_{\mathrm{BET}}$ ). Unpyrolyzed husks and stover were also used for soil amendments and compared to biochars in different proportions under a controlled incubation environment over 107 days. Fertilizers were not applied. An increase in water holding capacity, total organic carbon, cation exchange capacity, and a decrease in soil $\mathrm{CO}_{2}$ emission were observed after biochar application to soil versus the application of the parent husks or stover. These biochars improved soil fertility and enhanced eggplant crop growth (height, leaf number, fresh and dry weight). In addition, carbon mitigation was achieved because the biochar remained stable in the soil achieving longer term carbon sequestration. Both chars can be used for carbon sequestration and soil amendments.
\end{abstract}

\section{Introduction}

Rising concentration of the greenhouse gas (GHG), carbon dioxide, in the atmosphere is a major anthropogenic cause of climate change. ${ }^{1,2}$ The preindustrial atmospheric $\mathrm{CO}_{2}$ concentration of 255 to $280 \mathrm{ppm}^{1}$ has increased to $\sim 400 \mathrm{ppm} .^{3,4}$ The $\mathrm{CO}_{2}$ concentration could reach $700 \mathrm{ppm}$ or more in the twentyfirst century. ${ }^{1}$

Every year worldwide anthropogenic $\mathrm{CO}_{2}$ emissions from energy generation increase. By 2020, 33.8 billion metric tons per year could be emitted, up from 29.7 billion metric tons per year in $2007 .^{5}$ Added to anthropogenic $\mathrm{CO}_{2}$ emissions are those from fires, the natural carbon cycle, and deforestation. World agriculture accounted for an estimated emission of 5.1-6.1 $\times 10^{9}$ metric tons (5.1-6.1 Pg) $\mathrm{CO}_{2}$ equivalents year ${ }^{-1}$, contributing $10-12 \%$ to the total global anthropogenic GHG emissions in 2005. ${ }^{6,7}$ The changing climate impacts society and ecosystems in many harmful ways. ${ }^{8}$

Research to mitigate $\mathrm{CO}_{2}$ emissions, reduce the $\mathrm{CO}_{2}$ atmospheric concentration, and enhance soil fertility, crop production and bio-derived energy production would be welcome. ${ }^{9}$ Efforts to reduce $\mathrm{CO}_{2}$ emissions through carbon sequestration

${ }^{a}$ School of Environmental Sciences, Jawaharlal Nehru University, New Delhi 110067, India. E-mail: dm_1967@hotmail.com; Fax: +91-11-26704616; Tel: +91-11-26704616 ${ }^{b}$ Department of Chemistry, Mississippi State University, Mississippi State, MS 39762, USA

$\dagger$ Electronic supplementary information (ESI) available. See DOI: 10.1039/c7ra10353k include both reforestation ${ }^{\mathbf{1 0}}$ and $\mathrm{CO}_{2}$ injection into underground saline and other geological formations or into the deep ocean. ${ }^{11,12}$ Sequestering $C$ in soils as biochar can improve soil fertility, supplementing adding biosolids, organic waste fertilizers and improving crop rotation..$^{\mathbf{1 3}, \mathbf{1 4}}$ However, organic wastes and biosolids will decompose in the soil emitting $\mathrm{CO}_{2}$. Conversely, the carbon in biochars, originally removed from the atmosphere as $\mathrm{CO}_{2}$ during plant growth, persist in soils from decades to millennia. ${ }^{\mathbf{1 5 , 1 6}}$ Thus, if biochar application proves widely applicable at low cost in improving soil fertility in agriculture, its widespread use could lead to enhanced carbon sequestration. Biochar can be made either as a byproduct of fast pyrolysis to generate biooil $^{17}$ (a liquid fuel precursor) or slow pyrolysis. ${ }^{17-25}$ Biochar production technologies ${ }^{26}$ and $\mathrm{CO}_{2}$ capture, storage, and utilization have been reviewed. ${ }^{27-29} \mathrm{~A}$ strategy that combines biomass for energy production with application of byproduct biochar to soils more effectively mitigates $\mathrm{CO}_{2}$ then solely producing bioenergy. ${ }^{30}$

Application of biochar to soil is not new. For example, the Amazon basin (terra preta) contains huge amounts sequestered carbon as charred material. ${ }^{31}$ Biochar effects on soil depend on feedstock type, heating temperature, and residence time. ${ }^{32-34}$ Biochar can enhance plant growth, retain nutrients, provide habitat for microorganisms, ${ }^{\mathbf{1 5 , 1 6 , 3 3 , 3 5}}$ improve soil water holding capacity, ${ }^{36-38}$ soil water availability, ${ }^{39}$ and hydraulic conductivity. ${ }^{\mathbf{4 0}}$ Biochars can reduce net GHG emissions from agricultural soil, ${ }^{41,42}$ through mechanisms that are still not clear. ${ }^{32,34,43}$ A $50 \%$ reduction in nitrous oxide $\left(\mathrm{N}_{2} \mathrm{O}\right)$ and $100 \%$ reduction in 
methane $\left(\mathrm{CH}_{4}\right)$ emissions from soybean plots were achieved by adding biochar $\left(20 \mathrm{~g} \mathrm{~kg}^{-1}\right)$ to acidic soil in the Eastern Colombian Plains. ${ }^{41}$ An $85 \% \mathrm{~N}_{2} \mathrm{O}$ emission reduction from rewetted soil with $10 \%$ biochar was reported. ${ }^{42}$

Amending rice paddy soil with biochar reduced $\mathrm{CO}_{2}$ and increased $\mathrm{CH}_{4}$ emissions, ${ }^{44}$ but $\mathrm{CO}_{2}$ emissions are not always lowered by biochar. Both increases and decreases in $\mathrm{CO}_{2}$ emissions were reported in soils amended with 16 different types of biochars. ${ }^{45} \mathrm{CO}_{2}$ emission from Swiss loam soil was unchanged after adding pine wood biochar but increased with grass-derived biochar amendment. ${ }^{46}$ Agronomic benefits arising from biochar additions to the degraded soils have been emphasized, but negligible and negative agronomic effects have also been reported. ${ }^{47}$ Biochar use for organic composting wastes and remediation of soil contaminated with heavy metals and organics has been reviewed ${ }^{48}$ together with the advantages of combining biochar and compost for soil remediation and plant growth.

Crop residues represent a large amount of biomass. They are frequently left on fields after harvests as cover and then decompose, releasing $\mathrm{CO}_{2}$ back to atmosphere or used other ways or are simply burned. According to the Indian Ministry of New and Renewable Energy, biomass current availability is estimated at $\sim 500$ million metric tons per year in India alone. ${ }^{49}$ Residues are used as animal feed, home thatching, and for domestic and industrial fuel. Tragically, a large portion of unused crop residues are burned in the fields to clear the leftover straw and stubble after harvest, causing serious air pollution and producing $\mathrm{CO}_{2}$ contributing to global warming. It also causes a huge loss of carbon feedstock which can be used to improve soil fertility. One ton of biomass/stubble burning releases $2 \mathrm{~kg}$ of $\mathrm{SO}_{2}, 3 \mathrm{~kg}$ of $\mathrm{PM}, 60 \mathrm{~kg}$ of $\mathrm{CO}, 1460 \mathrm{~kg}$ of $\mathrm{CO}_{2}$, and $199 \mathrm{~kg}$ of ash. ${ }^{50}$ Burning of crop stubble adversely impacts those people suffering from respiratory and cardiovascular diseases. An example of the terrible consequences of crop residue burning was the unprecedented air pollution experienced in New Delhi from Nov. 06 to Nov. 10, 2017. Furthermore, long term burning also reduces total nitrogen and carbon in the 0 $15 \mathrm{~cm}$ soil layer along with a loss in soil organic matter. ${ }^{50} \mathrm{~A}$ sustainable alternative to this biomass burning is the conversion of agricultural residues into biochar. This biochar can then be used simultaneously to enhance soil fertility, carbon sequestration and crop growth.

A laboratory incubation study of biochar effects on $\mathrm{CO}_{2}$ soil emission is reported here. Its objectives were (a) to characterize rice husks, corn stover, and their biochars (RHBC and CSBC, respectively) as soil amendments, (b) to determine the biochar physical and chemical properties, and (c) to compare the $\mathrm{CO}_{2}$ emissions after addition of these amendments to soil. Additionally, the effects of biochar and biomass on eggplant (Solanum melongena) growth and soil quality were reported without the application of fertilizers.

\section{Experimental section}

\subsection{Biochar production}

Corn stover and rice husk agricultural wastes were collected from in and around Delhi [rice husk: Duhai village, Ghaziabad,
Uttar Pradesh, $28^{\circ} 43.995^{\prime}(\mathrm{N})$ and $77^{\circ} 28.603^{\prime}(\mathrm{E})$; corn stover: Chandni Chowk, Delhi, $28^{\circ} 39.44^{\prime}(\mathrm{N})$ and $\left.77^{\circ} 13.19^{\prime}(\mathrm{E})\right]$. These were pyrolyzed under $\mathrm{N}_{2}$ in a programmable temperature muffle furnace (Thermo Scientific, Model: F6000) equipped with programmable dwell time control. Rice husks and corn stover were air-dried and cut into 5-25 $\mathrm{mm}$ sizes. Rice husks were pyrolyzed to form $\mathrm{RHBC}$ at $550{ }^{\circ} \mathrm{C}$ while corn stover was pyrolyzed into CSBC at $650{ }^{\circ} \mathrm{C}$ at $10{ }^{\circ} \mathrm{C} \mathrm{min}^{-1}$ for both, followed by $30 \mathrm{~min}$ residence times at the pyrolysis temperature. Yields were $33.2 \%$ for RHBC and $29.7 \%$ for CSBC. The yields and properties depend on the biomass feed, pyrolysis temperature, residence time and heating rate. Yields decreased with a rise in temperature. Biochars were ground to pass through a $2 \mathrm{~mm}$ sieve before use.

\subsection{Equipment and reagents}

All chemicals were either analytical (AR) or general (GR) grade reagents. Ammonium acetate and sodium hydroxide were purchased from Merck, India. The $\mathrm{pH}$ and electrical conductivity (EC) were determined using a multi-parameter ion meter (Thermo Orion 5 star). $\mathrm{Na}^{+}$and $\mathrm{K}^{+}$analyses employed a flame photometer (CL-378, Elico, India). $\mathrm{Ca}^{2+}$ and $\mathrm{Mg}^{2+}$ were determined using AAS (Thermo Fisher Scientific M6 Mk2 Dual). Soilbiochar samples were blended using a rotospinner. C, N, and $\mathrm{H}$ analyses were determined with a EUROM EA3000 elemental analyzer. Moisture content, volatile matter and ash content were determined according to D1762-84. ${ }^{51}$ Feedstock, biochar and soil moisture contents were estimated by oven drying ( $2 \mathrm{~h}$ at $1 \mathrm{~atm})$ at $105{ }^{\circ} \mathrm{C}$. Volatiles were determined by weight loss upon heating to $950{ }^{\circ} \mathrm{C}$ for $11 \mathrm{~min}$. Ash content was estimated by weight loss on heating at $750{ }^{\circ} \mathrm{C}$ for $2 \mathrm{~h} .{ }^{52}$

FTIR spectra (KBr pellets) from 4000 to $400 \mathrm{~cm}^{-1}$ employed 8 scans at $4 \mathrm{~cm}^{-1}$ resolution (Perkin-Elmer model Varian 7000). Biochar powder X-ray diffraction patterns were recorded on a (PANalytical model X'Pert PRO) XRD system using $\mathrm{Cu} \mathrm{K \alpha}$ $(k=1.54 \AA)$ radiation at $45 \mathrm{kV}$. The samples were scanned from $5^{\circ}$ to $90^{\circ}$ at $2^{\circ} \mathrm{min}^{-1}$. Biochar morphology was examined by scanning electron microscopy (SEM) (Zeiss, Evo 40) at a $20000 \mathrm{~V}$ accelerating voltage and working distance: 10 000-10 $500 \mu \mathrm{m}$. Samples were coated with a thin gold layer, and mounted on a copper stab using a double stick carbon tape. Elemental compositions were determined by SEM/EDX analyses.

X-ray EDX analyses were carried out on sintered pellets using the Zeiss, EVO 40 SEM employing a Bruker EDX system and an energy dispersive X-ray fluorescence spectrometer (PANalytical Epilson 5) to determine surface region elemental compositions. RHBC and CSBC pellets with boric acid were compressed using an Insmart System (INSMART XRF 40) at 5 tons $/ 8 \mathrm{~mm}^{2}$.

CSBC and RHBC were examined by TEM at a $200 \mathrm{keV}$ using a model JEOL 2100F (Japan). Biochars were dispersed in warm Millipore water by ultrasonic mixing $(20 \mathrm{~min})$. Samples were deposited onto a carbon-coated grid.

CSBC and RHBC surface areas (BET) were determined using a Micromeritics ASAP 2020 surface area analyzer on $0.15 \mathrm{~g}$ samples out-gassed at $250{ }^{\circ} \mathrm{C}$ for $12 \mathrm{~h}$ at $<10^{-3}$ Torr. 
Carbon dioxide fluxes were measured by an automated soil $\mathrm{CO}_{2}$ infrared gas analyzer (non-dispersive) (LI-COR Biosciences LI-8100A). An airtight container (Fig. 1), was designed to conduct the incubation experiments. The $\mathrm{CO}_{2}$ fluxes were followed on a per second basis continuously for 2 min using wireless communication.

\subsection{Experimental design for $\mathrm{CO}_{2}$ flux measurements}

The $\mathrm{CO}_{2}$ chamber was used for $\mathrm{CO}_{2}$ flux measurements. An air tight circular polypropylene box [diameter: $120 \mathrm{~mm}$; length: $177 \mathrm{~mm}$ ] was purchased. Two metallic plugs were inserted in small holes made in the cap and sealed using silicone sealant. The inlet and outlet metallic plugs were connected to the soil$\mathrm{CO}_{2}$ flux analyzer by silicone tubing (diameter: $4 \mathrm{~mm}$ ) and LICOR connectors (Fig. 1). Air flow was controlled using stop cocks placed between metallic plug and LI-COR connectors.

\subsection{Soil treatments and incubation study}

Preliminary experiments used garden top soil $(0-30 \mathrm{~cm})$ collected from School of Environmental Sciences $\left(28^{\circ} 32.347^{\prime} \mathrm{N}\right.$, $77^{\circ} 10.049^{\prime}$ E), Jawaharlal Nehru University. Texture, water holding capacity, bulk density, soil organic matter fractions and total and available nutrients were all determined following standard methods elaborated in GOI, 2011.53,54

In $1000 \mathrm{ml}$ air tight containers, $500 \mathrm{~g}$ (dry weight) of soil (oven dried at $105{ }^{\circ} \mathrm{C}$ for $2 \mathrm{~h}$ ) was amended with biochars, rice husks or corn stover at different doses $(0.5,1.5$ and 3.0\% wt/wt). Soil without added amendment was designated as the control (Experimental design shown in Table SM1 $\dagger$ ). Prior to incubation, the soil was sieved through a $2 \mathrm{~mm}$ mesh size. Distilled water was added to achieve about $50 \%$ moisture content. The soil was then incubated at $25 \pm 1{ }^{\circ} \mathrm{C}$ and $65 \pm 5 \%$ relative humidity in the dark for $7 \mathrm{~d}$ to establish the microbial activity ${ }^{55}$ and placed in plastic boxes $(12.0 \mathrm{~cm}$ wide and $17.7 \mathrm{~cm}$ deep) to a soil depth of $8 \mathrm{~cm}$. After $7 \mathrm{~d}$ of pre-incubation, the soils were amended with rice husks, corn stover or the biochars at $0.5 \%$, $1.5 \%$ and $3.0 \%$ [weight/weight (wt/wt)] respectively. Subsequently, moisture content in all the samples was kept to $50 \%$. The incubation lasted for $107 \mathrm{~d}$. The following soil amendments were applied:
1. Soil was mixed with either $0.5 \%, 1.5 \%$ or $3.0 \%$ (wt/wt) biochar (RHBC or CSBC).

2. Soil was mixed with either $0.5 \%, 1.5 \%$ or $3.0 \%$ (wt $/ w t)$ of rice husks or corn stover.

The control (un-amended) soil, biochar-amended soils, and biomass-amended soils were placed into an indigenously designed $\mathrm{CO}_{2}$ chamber (Fig. 1). Incubation was carried out for 107 days at $25 \pm 1{ }^{\circ} \mathrm{C}$ and $65 \pm 5 \%$ relative humidity to compare the biochar's effect on physical and chemical properties of soil conditioned with biochar or biomass. Soil, biochar-amended soil, and biomass-amended soil samples were incubated in the dark in an environmental chamber (Macro Scientific Works Pvt. Ltd.) at a temperature of $25 \pm 1{ }^{\circ} \mathrm{C}$ and $65 \pm 5 \%$ relative humidity for 107 days. The period was selected based on an earlier study. ${ }^{56}$ The $\mathrm{CO}_{2}$ emissions from control soil, biomassamended soils and biochar-amended soils were measured. The physical chemical properties of all samples, before and after incubation, were also determined. The $\mathrm{CO}_{2}$ flux was then measured for $300 \mathrm{~s}$ using $2 \mathrm{~mm}$ diameter PVC collars [Fig. 1]. $\mathrm{CO}_{2}$ flux was measured on days $1,2,3,4,5,6,7,8,10,12,15,19$, $24,31,41,51,58,65,71,86,93,100$, and 107 .

\subsection{Physico-chemical properties}

Bulk densities and water holding capacities of all soil samples were determined by the Keen's box method. ${ }^{57}$ The $\mathrm{pH}$ values of water solutions containing biochar were measured at 1:20 (w/v) after stirring for over $1 \mathrm{~h}$. The electrical conductivity (EC) of biochar/water suspensions (1: $10 \mathrm{wt} / \mathrm{wt})$ was measured at $25{ }^{\circ} \mathrm{C}$. The cation exchange capacities and exchangeable cations $\left(\mathrm{Na}^{+}\right.$and $\mathrm{K}^{+}, \mathrm{Ca}^{2+}$ and $\left.\mathrm{Mg}^{2+}\right)$ of the control and biocharamended soil samples were determined by the ammonium acetate ( $\mathrm{pH} 7$ ) method. ${ }^{58,59}$ Soil organic carbon and organic matter were determined by the weight loss on ignition. ${ }^{58}$

\subsection{Pot trials}

Soil samples $(500 \mathrm{~g})$ were placed in plastic pots $(\sim 10.2 \mathrm{~cm}$ wide and $13.6 \mathrm{~cm}$ deep) and then mixed thoroughly with $0,0.5,1.5$ and $3.0 \% \mathrm{wt} / \mathrm{wt}$ of $\mathrm{RHBC}$ and CSBC, respectively. Eggplant (Solanum melongena) seeds were planted to determine the effects of CSBC and RHBC growth, number of leaves, total fresh weight and total dry weight. Triplicates of each sample were

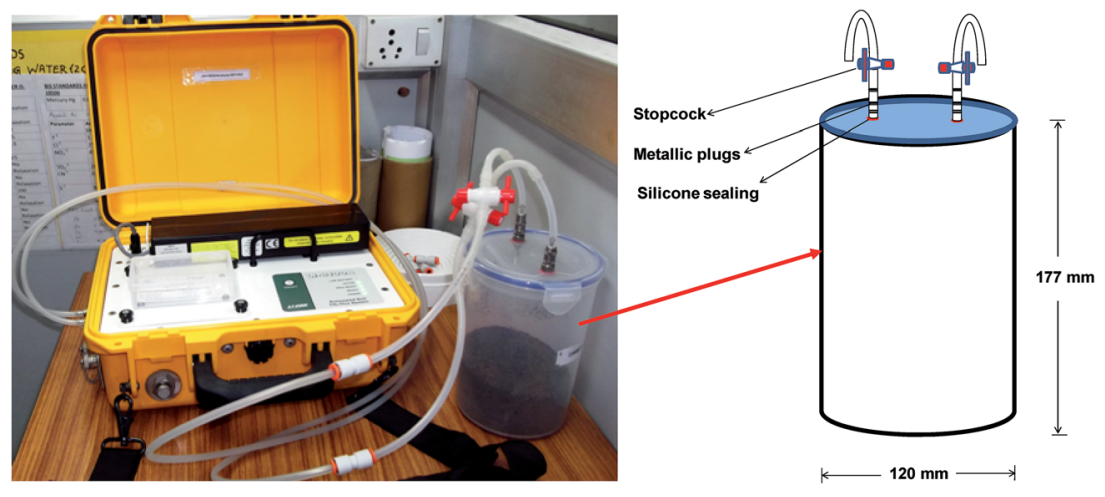

Fig. 1 Air tight sample container connected with LICOR LI-8100A used for incubation experiments. 
prepared (24 total samples). All pots were irrigated with water (60-70\% of water holding capacity) every day to maintain the soil moisture (70-80\%). The experiment was conducted for 7 weeks, during which the plant heights and number of leaves were measured weekly. Immediately after 7 weeks, whole plants were harvested. Their total fresh weights were measured immediately and total dry weights were measured after oven drying at $50{ }^{\circ} \mathrm{C}$ for 2 days. ${ }^{60}$ Plant heights were measured from the collar line to the longest leaf tip. ${ }^{61}$

\subsection{Statistical analysis}

Statistical analysis of the data was performed on the MS Excel (Windows 2007). The mean values of the replications were reported.

\section{Results and discussion}

\subsection{Biochar characterization}

A $29.7 \mathrm{wt} \%$ yield of corn stover biochar (CSBC) and $33.2 \mathrm{wt} \%$ of rice husk biochar (RHBC) were obtained upon slow pyrolysis based on the weight of the original biomass. Elemental and proximate analysis of biomass feedstocks, biochars and unamended soil are given in Table 1 . The water holding capacity was 1.5, 22.1 and 14.4 (wt\%) for soil, CSBC and, RHBC respectively. The sand, silt and clay contents in the soil were 24,70 and $6 \%$, respectively. The CSBC had a higher carbon and hydrogen content then RHBC [C (77.50 vs. $74.37 \%)$ and $\mathrm{H}(2.21$ versus $1.78 \%)]$. Biochar properties depend on the pyrolysis conditions (temperature, residence time, and reactor type) and feedstock. CSBC and RHBC were prepared at $650{ }^{\circ} \mathrm{C}$, and $550{ }^{\circ} \mathrm{C}$, respectively, contributing to the higher carbon content in CSBC. ${ }^{62-65}$ The degree of a char's carbonization is described by the molar $\mathrm{H} / \mathrm{C}$ ratio. ${ }^{66}$ The molar $\mathrm{H} / \mathrm{C}$ ratio was 1.54 and 1.44 for the CSBM and RHBM feeds, whereas this ratio for the corresponding biochars was 0.34 and 0.29 , respectively (Table 1 ). The decrease in $\mathrm{H} / \mathrm{C}$ ratio in the biochars clearly illustrates the high carbonization of the original lignocellulosic (organic) residue structure. ${ }^{62}$ The molar $\mathrm{O} / \mathrm{C}$ ratio is an indicator of biochar's surface hydrophilicity because it reflects polar-group content mostly derived from carbohydrates. ${ }^{62}$ The $\mathrm{O} / \mathrm{C}$ ratios of 0.70 and 0.94 for corn stover and rice husks dropped to 0.18 and 0.23 for CSBC and RHBC, respectively (Table 1). The O/C mole ratios suggest RHBC is more hydrophilic then CSBC. High hydrophilicity of RHBC is due to the presence of high silica $(\sim 49 \%)$ versus CSBC (3\%) [Table SM2 $\dagger$ ]. The tiny $\mathrm{SiO}_{2}$ particle surfaces have hydrophilic $\mathrm{Si}-\mathrm{OH}$ groups which contribute to overall $\mathrm{RH}$ and RHBC hydrophilic properties.

CSBC and RHBC surface areas $\left(\mathrm{S}_{\mathrm{BET}}\right)$ were 242.7 and $95.2 \mathrm{~m}^{2}$ $\mathrm{g}^{-1}$ (Fig. SM1 $\dagger$ ), respectively, while the total pore volumes were 0.12 (CSBC) and 0.06 (RHBC) $\mathrm{cm}^{3} \mathrm{~g}^{-1}$. The lower RHBC surface area results partially from its lower pyrolysis temperature $\left(550{ }^{\circ} \mathrm{C}\right)$ employed and high ash content. Biochar surface areas typically increase with higher pyrolysis temperature. ${ }^{24,62,67-70}$

Soil water holding capacities, structures, existing microbial communities, and earth worm populations may be altered by biochar application. ${ }^{71}$ Water holding capacity increased from $11.2 \mathrm{wt} \%$ for the control soil to $21.8 \mathrm{wt} \%$ upon addition to soil of $3.0 \mathrm{wt} \%$ of RHBC or $29.7 \mathrm{wt} \%$ with $3.0 \mathrm{wt} \%$ of CSBC. The increase in water holding capacity is greater for CSBC-amended soils than using RSBC at 0.5, 1.5, and $3.0 \mathrm{wt} \%$ levels (Table 2).

SEM micrographs of CSBC and RHBC (Fig. 2) illustrate their highly porous structures. Visual inspection illustrates microstructure differences between these chars. Distinct macro pores are observable in both. $\mathrm{Ca}^{2+}, \mathrm{Mg}^{2+}, \mathrm{Na}^{+}$and $\mathrm{K}^{+}$distributions on char surfaces were evident in SEM-EDX spectra (Fig. SM2 $\uparrow$ ). The TEM images and TEM elemental mapping of RHBC and CSBC appear in Fig. 3 and 4, respectively. [Fig. 4(A) and (B)] clearly shows $\mathrm{Si}^{4+}, \mathrm{K}^{+}$and $\mathrm{Mg}^{2+}$ predominate on surface regions RHBC versus $\mathrm{K}^{+}$and $\mathrm{Na}^{+}$on CSBC. This might be related to the high (49 wt\%) silica ash content in RHBC (Table SM2†). Tiny somewhat spherical primary particles are seen in RHBC at high magnification [Fig. 3].

The XRD patterns for RHBC and CSBC are shown in Fig. 5. The broad hump in the region between $18.84^{\circ}-28.15^{\circ}$ in both the

Table 1 Elemental and proximate analysis of biomass feedstocks, biochars ${ }^{b}$ and un-amended soil

\begin{tabular}{|c|c|c|c|c|c|c|c|c|c|c|c|}
\hline \multirow[b]{2}{*}{ Sample } & \multicolumn{3}{|c|}{$\begin{array}{l}\text { Elemental } \\
\text { composition }^{a}(\mathrm{wt} \%)\end{array}$} & \multicolumn{4}{|c|}{ Proximate analysis $^{a}$} & \multirow[b]{2}{*}{$\begin{array}{l}\text { Biochar } \\
\text { yield (\%) }\end{array}$} & \multicolumn{3}{|c|}{ Atomic ratio (\%) } \\
\hline & $\mathrm{C}$ & $\mathrm{H}$ & $\mathrm{N}$ & $\begin{array}{l}\text { Moisture } \\
\text { content (\%) }\end{array}$ & Ash (\%) & $\begin{array}{l}\text { Volatile } \\
\text { matter (\%) }\end{array}$ & $\begin{array}{l}\text { Fixed } \\
\text { carbon (\%) }\end{array}$ & & $\mathrm{C} / \mathrm{N}$ & $\mathrm{H} / \mathrm{C}$ & $\mathrm{O} / \mathrm{C}$ \\
\hline $\begin{array}{l}\text { Corn stover feedstock } \\
\text { (CSBM) }\end{array}$ & 44.24 & 5.66 & 8.58 & 5.64 & 1.70 & 81.38 & 11.28 & - & 6.01 & 1.53 & 0.70 \\
\hline $\begin{array}{l}\text { Corn stover biochar } \\
\text { (CSBC) }\end{array}$ & 77.51 & 2.21 & 1.50 & 1.21 & 4.06 & 18.10 & 76.63 & 29.7 & 64.12 & 0.34 & 0.18 \\
\hline $\begin{array}{l}\text { Rice husk biochar } \\
\text { (RHBC) }\end{array}$ & 74.37 & 1.78 & 1.02 & 0.14 & 2.43 & 14.85 & 82.58 & 33.2 & 85.06 & 0.29 & 0.23 \\
\hline Soil & 1.49 & 0.83 & - & 0.53 & - & - & - & - & - & 6.67 & 49.51 \\
\hline
\end{tabular}

${ }^{a}$ On dry basis. ${ }^{b}$ To maintain uniformity, a number $(n=5)$ of biochar samples were randomly picked from thoroughly mixed (using Quadrate method) bulk biochar. These samples were then mixed well again using quadrate method at least 10 times. Then a small sample size is picked for analysis. 
Table 2 Effect of biochar on soil properties after 107 days

\begin{tabular}{|c|c|c|c|c|c|c|c|}
\hline Parameters & \multicolumn{7}{|c|}{ Biochar amendments $^{c}$} \\
\hline $\mathrm{pH}$ & $7.37 \pm 0.66$ & $7.61 \pm 0.49$ & $7.72 \pm 0.80$ & $8.01 \pm 0.57$ & $7.89 \pm 0.21$ & $8.14 \pm 0.29$ & $8.20 \pm 0.28$ \\
\hline $\mathrm{EC}\left(\mu \mathrm{S} \mathrm{cm}{ }^{-1}\right)$ & $248 \pm 2$ & $340 \pm 3$ & $464 \pm 2$ & $497 \pm 3$ & $220 \pm 2$ & $291 \pm 2$ & $466 \pm 2$ \\
\hline Organic matter (wt\%) & $0.82 \pm 0.10$ & $1.64 \pm 0.33$ & $3.63 \pm 0.43$ & $8.21 \pm 0.56$ & $1.59 \pm 0.46$ & $1.95 \pm 0.51$ & $4.80 \pm 0.61$ \\
\hline $\begin{array}{l}\text { Cation exchange capacity (meq./ } \\
100 \mathrm{~g} \text { ) }\end{array}$ & $4.2 \pm 0.7$ & $5.1 \pm 0.7$ & $5.3 \pm 0.9$ & $36.0 \pm 0.7$ & $19.6 \pm 0.7$ & $23.2 \pm 0.7$ & $29.9 \pm 0.7$ \\
\hline
\end{tabular}
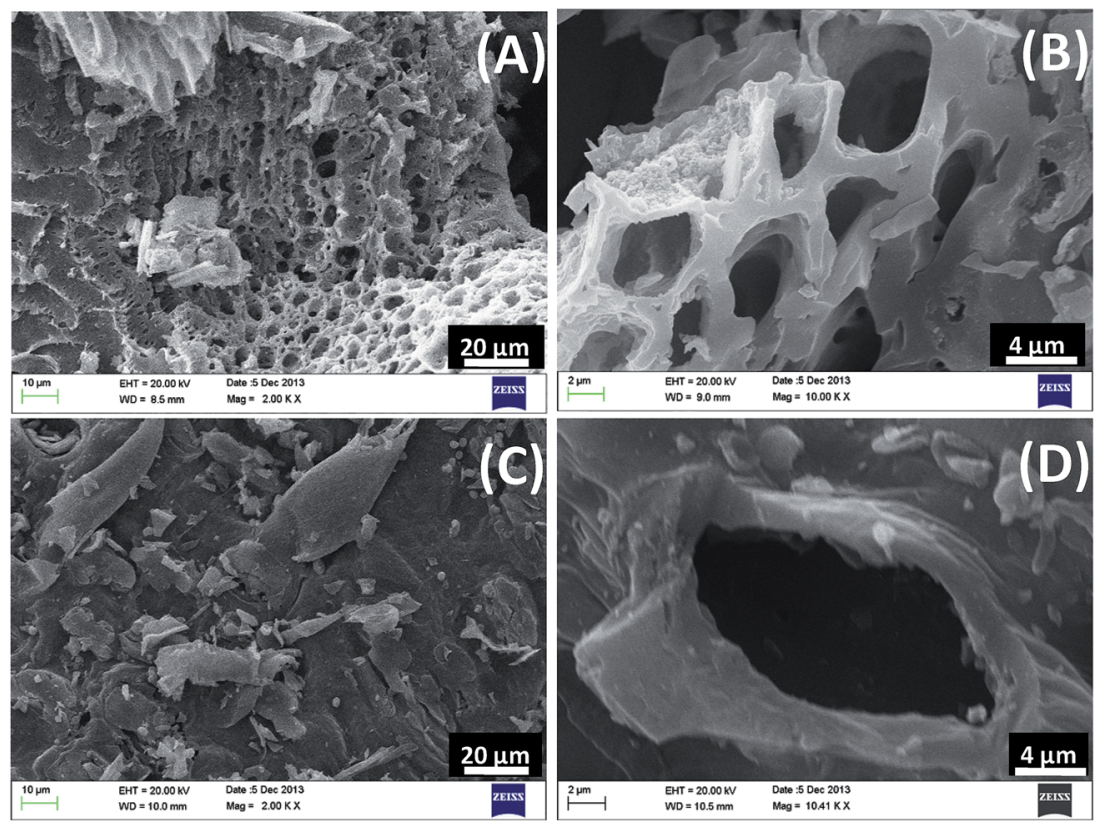

Fig. 2 SEM micrographs of rice husk biochar (RHBC) at (A) 2KX (B) 10KX and corn stover biochar (CSBC) at (C) 2KX (D) 10.41KX magnifications.

biochars is due to the crystal plane index $\mathrm{C}(002) \cdot{ }^{72,73}$ This $\mathrm{C}(002)$ plane is due to parallel and azimuthal orientation of the aromatic, partially carbonized lamellae. Sharper peaks are indicative of higher degree of orientation. Similarly, another broad hump in the region $42.18^{\circ}-46.78^{\circ}$ in both the biochars is due to crystal plane index of $\mathrm{C}(100)$. This $\mathrm{C}(100)$ peak is due to condensed aromatic carbonized planes. Thus, peaks depict appearance of a degree of crystalline orientation of $\mathrm{C}$ in biochar samples. ${ }^{72,73}$

Sharp and small peaks respectively at $26.59^{\circ}$ and $67.84^{\circ}$ in both CSBC and RHBC and $72.60^{\circ}$ in CSBC are due to $\mathrm{SiO}_{2}$ (quartz) (JCPDS card no. 46-1045). ${ }^{74} \mathrm{~A}$ strong peak at $38.42^{\circ}$ in CSBC and RHBC is due to CaO (lime) (JCPDS Card no. 011-1160) while the peak at $50.54^{\circ}$ in $\mathrm{CSBC}$ is due to $\mathrm{Ca}(\mathrm{OH})_{2}$ (JCPDS card no. 01-073-5492). ${ }^{75}$ Peaks at $44.67^{\circ}$ and $78.69^{\circ}$ indicate the presence of $\mathrm{CaCO}_{3}$ (calcite) in both CSBC and RHBC (JCPDS card no. 05-0586). ${ }^{76}$ Small peaks at $65.14^{\circ}$ and $82.64^{\circ}$ in CSBC and RHBC show $\mathrm{MnO}_{2}$ (JCPDS Card no. 44-0141), ${ }^{77}$ and $\mathrm{Al}_{2} \mathrm{O}_{3}$ (alumina) (JCPDS Card no. 11-0517), ${ }^{78}$ are present, respectively.
The FTIR spectra of CSBC and RHBC were similar with broad -OH stretching bands from organic or inorganic components found from $4000-3000 \mathrm{~cm}^{-1}$ (Fig. 6). Broad peak in the region from $3923-3367 \mathrm{~cm}^{-1}$ is attributed to $-\mathrm{OH}$ group stretching bands from organic and inorganic components rich in hydroxide groups or residual water, ${ }^{79}$ and possibly some mineral based $\mathrm{Si}-$ $\mathrm{OH}^{80}$ Small peaks at $2853 \mathrm{~cm}^{-1}$ and $2921 \mathrm{~cm}^{-1}$ in both RHBC and CSBC are assigned to $\mathrm{C}-\mathrm{H}$ symmetric stretching vibration in organic carbon. ${ }^{\mathbf{8 0 , 8 1}}$ Sharp peaks in RHBC and CSBC at $2357 \mathrm{~cm}^{-1}$ are due to $\mathrm{CO}_{2}$. The typical region between $2000-2400 \mathrm{~cm}^{-1}$ corresponds to $\mathrm{O}=\mathrm{C}=\mathrm{O},-\mathrm{C} \equiv \mathrm{C}-$ and $-\mathrm{C} \equiv \mathrm{N}$ triple bond stretching. Hence peaks at $2345 \mathrm{~cm}^{-1}$ in both RHBC and CSBC are tentatively assigned to $-\mathrm{C} \equiv \mathrm{C}-$ and the peak at $2369 \mathrm{~cm}^{-1}$ in $\mathrm{CSBC}$ to $-\mathrm{C} \equiv \mathrm{N}$ stretching present in the pyrolyzed carbonaceous material. ${ }^{82}$ Several unsymmetrical peaks in the broad region from 1926-1314 $\mathrm{cm}^{-1}$ with the peak maxima at $1685 \mathrm{~cm}^{-1}$ in $\mathrm{RHBC}$ and CSBC include contributions from $\mathrm{C}=\mathrm{O}$ stretching of the various functional groups in ketones, carboxylic acids, esters, 

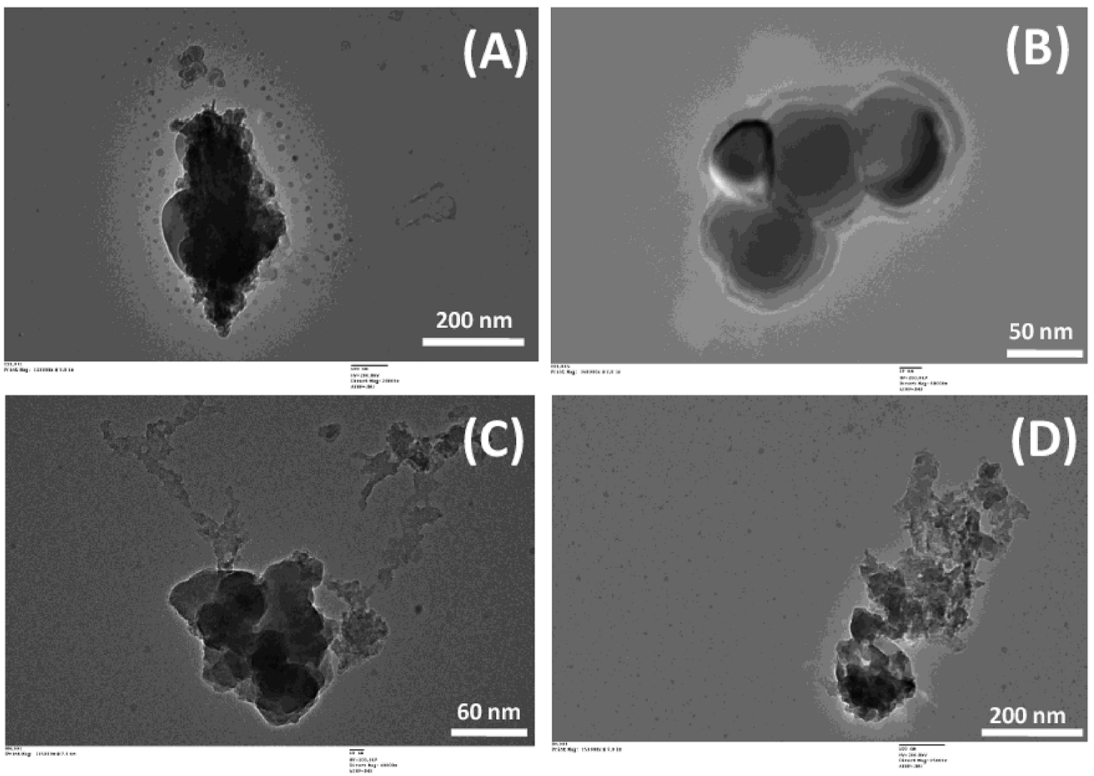

Fig. 3 TEM micrographs of corn stover biochar (CSBC) at (A) 20KX (B) 60KX and rice husk biochar (RHBC) at (C) 40KX (D) $250 \mathrm{KX}$ magnifications.
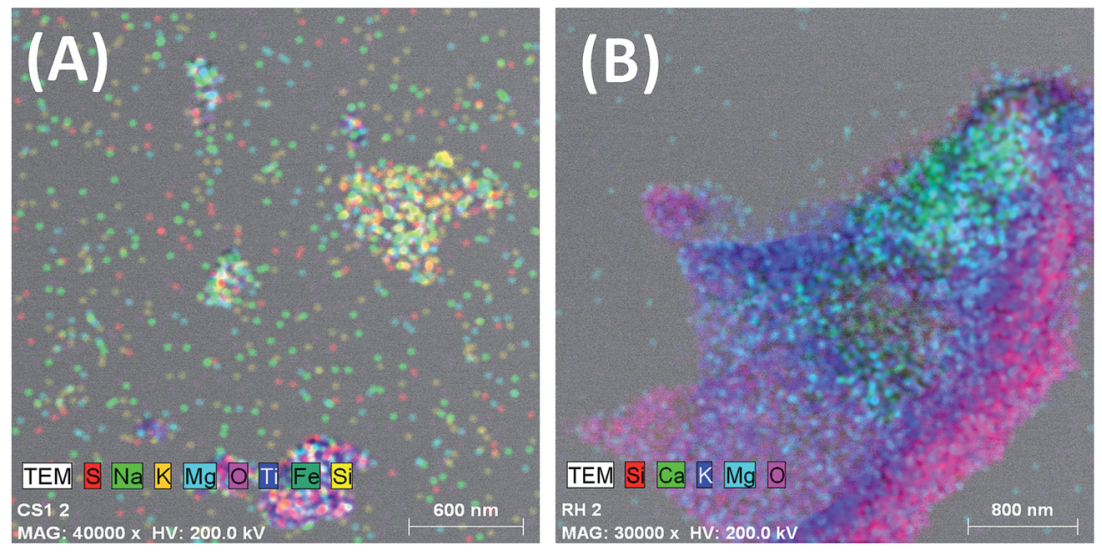

Fig. 4 TEM mapping of (A) corn stover biochar (CSBC) and (B) rice husk biochar (RHBC) showing constituent elements.

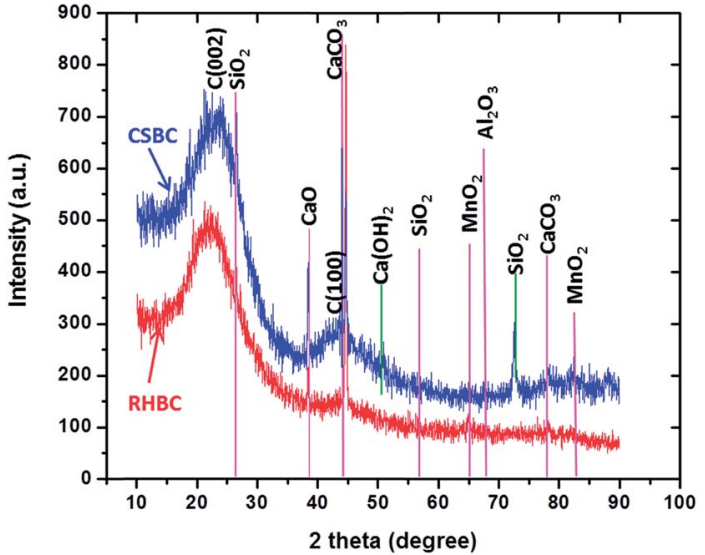

Fig. 5 XRD diffraction patterns from corn stover biochar (CSBC) and rice husk biochar (RHBC). and anhydrides and complex conjugated $\mathrm{C}=\mathrm{C}$ systems in the samples. ${ }^{83}$ The peak at $1550 \mathrm{~cm}^{-1}$ in both RHBC and CSBC is attributed to $\mathrm{C}=\mathrm{C}$ bond stretch in aromatic rings. ${ }^{84}$ The $\mathrm{RHBC}$ peak at $1109 \mathrm{~cm}^{-1}$ is assigned to $-\mathrm{C}-0 .{ }^{85}$ The band at $876 \mathrm{~cm}^{-1}$ in both the biochars is due to carbonate $-\mathrm{C}=\mathrm{O}$ stretching present in calcite. ${ }^{81,86,87}$ Peaks in the region $792 \mathrm{~cm}^{-1}$ and $464 \mathrm{~cm}^{-1}$ are due to asymmetric bending vibrations of $\mathrm{Si}-\mathrm{O}-\mathrm{Si}$ and symmetric stretching vibrations of $\mathrm{Si}-\mathrm{O}$, respectively in $\mathrm{RHBC}^{79}$ These peaks are however very weak or absent in CSBC in accord with $49 \%$ vs. $3 \%$ wt of $\mathrm{SiO}_{2}$ in $\mathrm{RHBC}$ vs. CSBC. Small peak at $690 \mathrm{~cm}^{-1}$ in both RHBC and CSBC is due to Si-O-Si stretching. ${ }^{79}$

\subsection{Change in the soil properties with biochar treatment}

3.2.1 $\mathrm{pH}$ and electrical conductivity (EC). The $\mathrm{pH}$ of water suspensions of CSBC and RHBC are higher (more basic) than those of a water suspension of control soil. The high biochar $\mathrm{pH}$ values are due to the basic oxides, hydroxides, and perhaps 


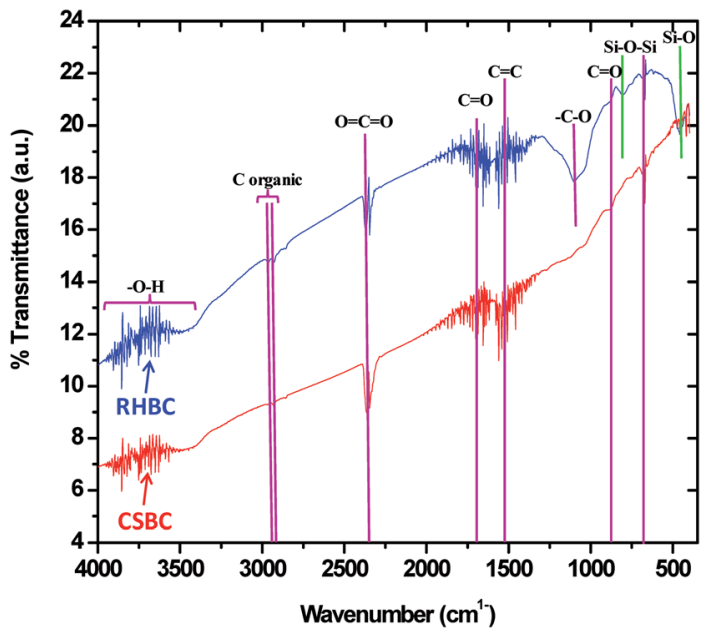

Fig. 6 FTIR spectra of rice husk biochar (RHBC) and corn stover biochar (CSBC).

carbonates formed from $\mathrm{Na}^{+}, \mathrm{K}^{+}, \mathrm{Ca}^{2+}$ and $\mathrm{Mg}^{2+}$ ions during pyrolyses to form the biochars. These metal ions were present in the original biomass feedstock as indicated by data in Table $\mathrm{SM} 2 \dagger$ and EDX analyses (Fig. SM2†). ${ }^{24}$ The EC values of CSBC or RHBC water suspensions are also higher than those of the control soil. Furthermore, the EC for soil mixed with $0.5 \mathrm{wt} \%$ RHBC $\left(220 \mu \mathrm{S} \mathrm{cm}^{-1}\right)$ was slightly lower than that of soil control $\left(248 \mu \mathrm{S} \mathrm{cm}^{-1}\right)$. The $\mathrm{pH}$ of CSBC and RHBC-treated soils increases by 0.3 to 0.8 units, respectively (Table 2). Both $\mathrm{pH}$ and EC of the soil continued to increase as more biochar was added. Others also observed a soil $\mathrm{pH}$ increase after biochar application. ${ }^{\mathbf{8 8 , 8 9}}$ Another reason soil $\mathrm{pH}$ could rise is an increase in soil cation exchange capacity (CEC) due to the biochars' high surface areas and porosity. ${ }^{90}$

3.2.2 Organic carbon and organic matter. Amending soil with biochar leads to significant increase in soil organic carbon after 107 day growing period. These values rise with increasing biochar application rates (Table 2). Biochar treatment (3.0\% wt/ wt) results in a final increase of soil organic carbon content by $328 \%$ for CSBC addition and $417 \%$ for RHBC addition above that of the control soil by the end of the 107 day growth period. Similar results have been reported earlier. ${ }^{15,20,91}$

3.2.3 Cation exchange capacity (CEC). The CEC of soils is a measure for how well cationic nutrients are bound to the soil, available for plant uptake, and 'prevented' from leaching to ground and surface waters. ${ }^{92}$ Amending soil with biochar increases $\mathrm{Na}^{+}, \mathrm{K}^{+}, \mathrm{Ca}^{2+}$ and $\mathrm{Mg}^{2+}$ availability and also the amended soil's CEC versus non-amended soil (Table 2). Higher total carbon and CEC values benefit crop productivity. ${ }^{15,91,93}$ The CECs of RHBC (10.2 meq./100 g) and CSBC (96.5 meq./100 g) are higher than that of un-amended soil (4.2 meq./100 g) (Table 2). The high biochar CEC values are attributed to their high surface area and significant retained oxygen content. ${ }^{94}$ The biochar oxygen content includes carbonyl, carboxyl and phenolic groups, which facilitate CEC. Thus, biochar increases soil CEC while also serving as a long term carbon sequestration agent. ${ }^{95}$ In our work, the CEC
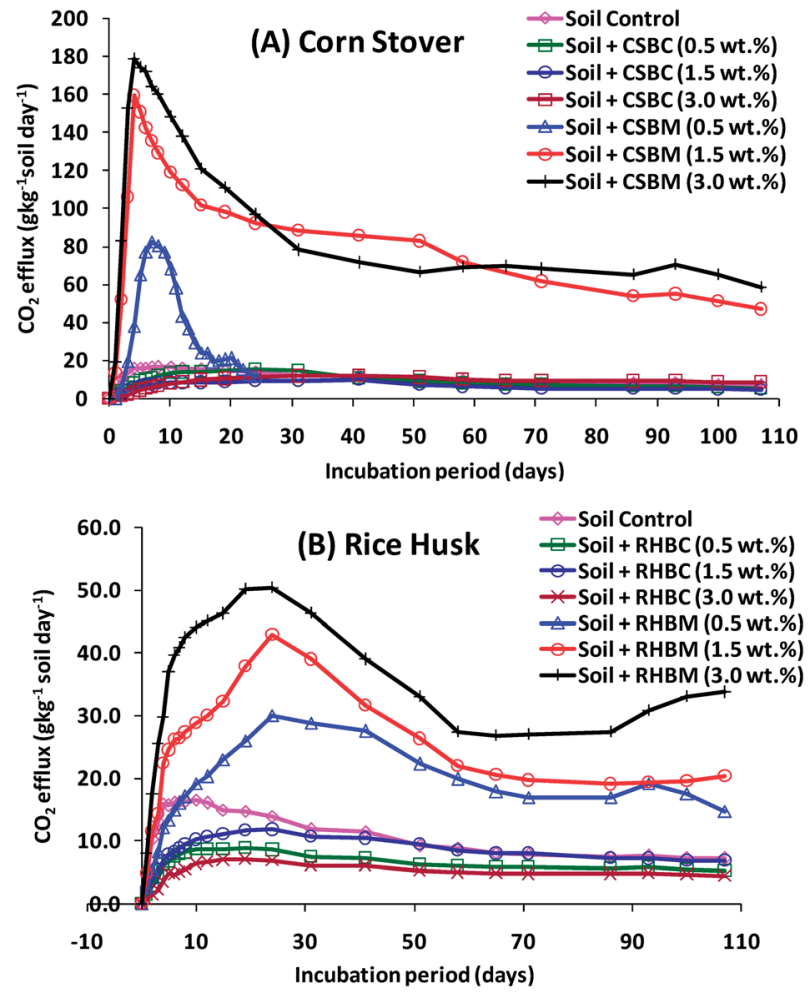

Fig. $7 \mathrm{CO}_{2}-\mathrm{C}$ efflux rate emitted from the soil control versus when soil was amended with $(A)$ rice husk biochar $(\mathrm{RHBC})$ or rice husk biomass (RHBM) and (B) corn stover biochar (CSBC) or corn stover biomass (CSBM). Soil control = soil without any amendment, soil + $\mathrm{RHBC}(0.5 \%)=$ soil amended with $0.5 \mathrm{wt} \%$ rice husk biochar, soil + $\mathrm{RHBC}(1.5 \%)=$ soil amended with $1.5 \mathrm{wt} \%$ rice husk biochar, soil + RHBC $(3.0 \%)=$ soil amended with 3.0 wt\% rice husk biochar, soil + $\operatorname{RHBM}(0.5 \%)=$ soil amended with 0.5 wt $\%$ rice husk biomass, soil + RHBM $(1.5 \%)=$ soil amended with $1.5 \mathrm{wt} \%$ rice husk biomass, soil + RHBM $(3.0 \%)=$ soil amended with $3.0 \mathrm{wt} \%$ rice husk biomass, soil + $\operatorname{CSBC}(0.5 \%)=$ soil amended with $0.5 \mathrm{wt} \%$ corn stover biochar, soil + CSBC $(1.5 \%)=$ soil amended with $1.5 \mathrm{wt} \%$ corn stover biochar, soil + $\operatorname{CSBC}(3.0 \%)=$ soil amended with 3.0 wt $\%$ corn stover biochar, soil + $\operatorname{CSBM}(0.5 \%)=$ Soil amended with $0.5 w t \%$ corn stover biomass, soil + CSBM $(1.5 \%)=$ Soil amended with $1.5 \mathrm{wt} \%$ corn stover biomass and soil + CSBM $(3.0 \%)=$ soil amended with 3.0 wt\% corn stover biomass.

increased by $316 \%$ (CSBC, $0.5 \mathrm{wt} \%$ ), 321\% (CSBC $1.5 \mathrm{wt} \%$ ) and $362 \%$ (CSBC $3.0 \mathrm{wt} \%$ ) versus the control soil. Similarly, the CEC increased by $471 \%$ (RHBC, $0.5 \mathrm{wt} \%$ ), 585\% (RHBC, $1.5 \mathrm{wt} \%$ ), and $719 \%$ (RHBC, $3.0 \mathrm{wt} \%$ ) versus the soil control. Slow biochar oxidation in the soil has been reported to increase the number of the char's carboxyl groups, which in turn increase the soil's CEC. ${ }^{20}$ Other biochars have high CEC values with a high recalcitrance and the highest biochar applications give the highest CEC values in accord with our results. ${ }^{16}$ Relatively high CEC values explain, in part, the ability of biochars to retain nutrients in the soil. Biochartreated soil may also provide adsorption sites that help in maintaining nutrient availability. ${ }^{96}$ Biochars with surface areas $>100 \mathrm{~m}^{2} \mathrm{~g}^{-1}$ have significant potential for improving both water and nutrient retention in soil and soil porosities that often benefit both microbes and plants. ${ }^{97}$ 

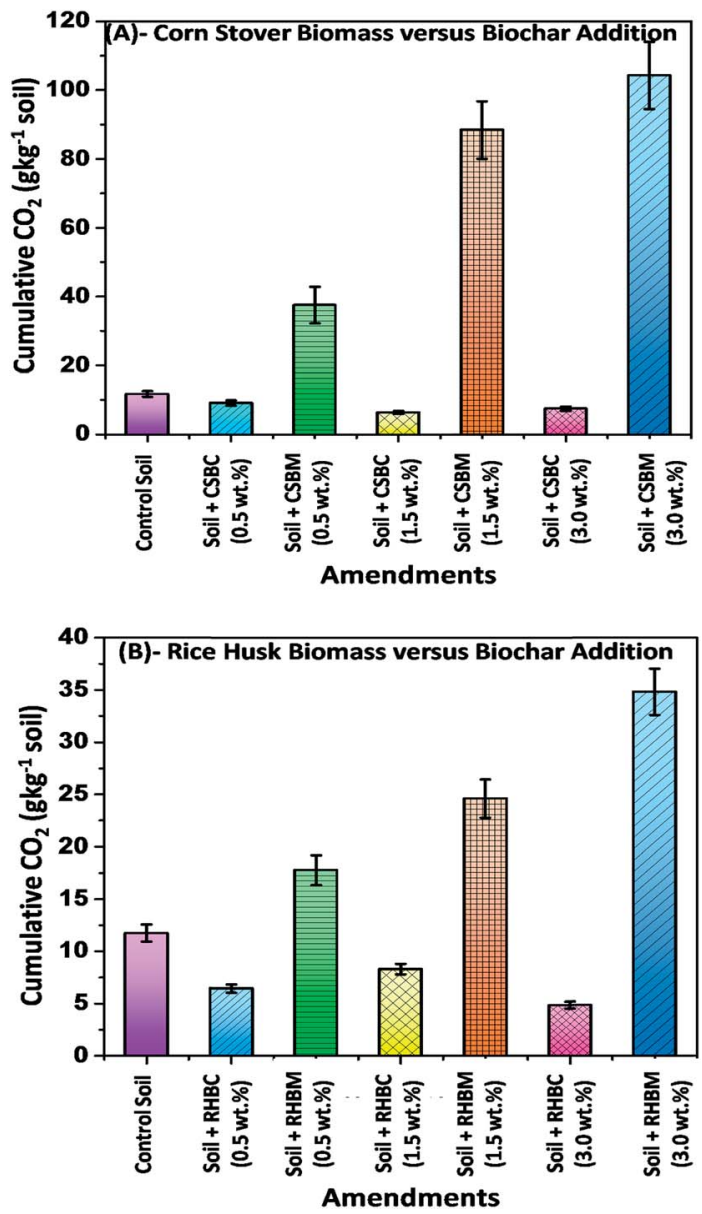

Fig. 8 Cumulative $\mathrm{CO}_{2}-\mathrm{C}$ emission from soil amended with different biochar and biomass doses (wt\%) (A) corn stover biochar (CSBC) and corn stover biomass (CSBM) and (B) rice husk biochar (RHBC) and rice husk biomass (RHBM) during incubation period of 107 days. For treatment abbreviations see figure. Error bars represent standard error of the mean $(n=3)$ and $p>0.05$.

\subsection{Soil respiration: effect of biochar and biomass addition on soil $\mathrm{CO}_{2}$ release}

The effect of adding biochar (CSBC and RHBC) versus its precursor biomass (corn stover and rice husks) on soil $\mathrm{CO}_{2}$ emissions during a 107 day incubation period is depicted in Fig. 7. Cumulative $\mathrm{CO}_{2}$ emissions are summarized in Fig. 8 . These $\mathrm{CO}_{2}$ emissions are expressed as the $\mathrm{g} \mathrm{kg}^{-1}$ of soil per day.

Adding corn stover to soil at levels 0.5, 1.5 and $3.0 \mathrm{wt} \%$ resulted in higher $\mathrm{CO}_{2}$ emissions $\left(\mathrm{g} \mathrm{CO}_{2} \mathrm{~kg}^{-1}\right.$ soil day $\left.{ }^{-1}\right)$ than those emitted from either of the biochar-amended soils (CSBC and RHBC) or the control soil. The $\mathrm{CO}_{2}$ emissions order was corn stover-amended soil $>$ control soil $>$ corn stover biocharamended soil. The $\mathrm{CO}_{2}$ efflux $\left(\mathrm{g} \mathrm{CO}_{2} \mathrm{~kg}^{-1}\right.$ soil day $\left.{ }^{-1}\right)$ from both biomass-amended soils increased during the first two weeks of incubation. It reached a maximum rate on the $15^{\text {th }}$ day for corn stover-amended soil versus $24^{\text {th }}$ day with rice huskamended soil. This efflux occurs as the added biomass decomposes. Higher biomass additions, as expected, led to greater $\mathrm{CO}_{2}$ emissions [Fig. 7(A) and (B)]. For example, the $\mathrm{CO}_{2}$ emissions order was: corn stover $3.0(\mathrm{wt} \%)>1.5(\mathrm{wt} \%)>0.5$ (wt\%), respectively [Fig. 7(A)]. After incubating for two weeks, the $\mathrm{CO}_{2}$ efflux in all cases decreased with longer incubation times. After 107 days, the cumulative $\mathrm{CO}_{2}$ emission was higher for corn stover-amended soil than for rice husk-amended soil [Fig. 8(A) and (B)]. Both biomass-amended soils gave higher total $\mathrm{CO}_{2}$ emissions than the control. The cumulative total emissions were $37.48,88.44$ and $104.25\left(\mathrm{~g} \mathrm{CO}_{2} \mathrm{~kg}^{-1}\right.$ soil) in soils amended with $0.5,1.5$, and $3.0 \mathrm{wt} \%$ by weight of corn stover, respectively, versus only $11.74 \mathrm{~g} \mathrm{CO}_{2} \mathrm{~kg}^{-1}$ soil for the control [Fig. 8(A)]. Overall, $\mathrm{CO}_{2}$ emissions for corn stover-modified soil were greater than those of soil modified by equivalent weights of rice husks. This was expected given the greater ash content and smaller carbon content of rice husks.

In contrast to biomass addition, biochar addition lowered $\mathrm{CO}_{2}$ emissions (Fig. 7 and 8). CSBC and RHBC addition to soil lowered cumulative $\mathrm{CO}_{2}$ emissions for all of the biochar addition levels versus the control soil. The $\mathrm{CO}_{2}$ efflux increased during the first 24-41 days of incubation for CSBC-amended soil. Similar $\mathrm{CO}_{2}$ emission trends were reported for other biochars. ${ }^{98,99}$ The cumulative $\mathrm{CO}_{2}$ emissions were highest in the soil amended with 0.5 (wt\%) followed by 1.0 (wt\%) and 3.0 (wt\%) CSBC, respectively [Fig. 8(A)]. After 24-41 days, the $\mathrm{CO}_{2}$ efflux drops with longer incubation times regardless of biochar dose. The cumulative total emissions were 9.12, 6.37, 7.45 (g $\mathrm{CO}_{2} \mathrm{~kg}^{-1}$ soil) in soils amended with $0.5,1.5$, and $3.0 \mathrm{wt} \%$ of CSBC, respectively, and $11.74 \mathrm{~g} \mathrm{CO}_{2} \mathrm{~kg}^{-1}$ soil for the control soil. Soil amended with $3.0 \%$ of CSBC emitted $\sim 157 \%$ less $\mathrm{CO}_{2}$ over 107 days than to the control soil [Fig. 8(A)].

Similar $\mathrm{CO}_{2}$ efflux trends were obtained with rice husk- or RHBC-amended soils [Fig. 7(B) and 8(B)]. Rice husk addition to soil led to much higher $\mathrm{CO}_{2}$ emissions at all levels versus the control soil. $\mathrm{CO}_{2}$ efflux increased during incubation during the first 10 days for the control soil and 19-24 days for the soils amended with RHBC. This is seen immediately looking at the figures [Fig. 7(B) and 8(B)].

The $\mathrm{CO}_{2}$ efflux from the control soil reached a maximum rate on the $10^{\text {th }}$ day versus 19-24 days for RHBC-amended soils. The $\mathrm{CO}_{2}$ emissions rose as more rice husks were added $(3.0>1.5>$ $0.5 \mathrm{wt} \%)$ [Fig. 7(B)]. After $\mathrm{CO}_{2}$ emissions reached their maximum values they all decreased at longer incubation times. After 107 days, the cumulative $\mathrm{CO}_{2}$ emission was higher for rice husk-amended soils versus either the control or RHBC-amended soil. The cumulative total emissions were $17.80,24.62$, and $34.83 \mathrm{~g} \mathrm{CO}_{2} \mathrm{~kg}^{-1}$ soil for soils amended with $0.5,1.5$ and $3.0 \mathrm{wt} \%$ of RHBM [Fig. 8(B)]. $\mathrm{CO}_{2}$ emissions by three RHBCamended soils remained lower than the control soil for about 30 days. Soil amended with 3.0\% RHBC emitted $\sim 716 \%$ and $\sim 241 \%$ less $\mathrm{CO}_{2}$ over 107 days versus the RHBM-amended and control soils, respectively [Fig. 8(B)]. Cumulative $\mathrm{CO}_{2}$ releases of 6.46, 8.32, and $4.86\left(\mathrm{~g} \mathrm{CO}_{2} \mathrm{~kg}^{-1}\right.$ soil) were measured for $0.5,1.5$, and $3.0 \mathrm{wt} \%$ of RHBC additions, respectively [Fig. 8(B)].

Biochar doesn't "rot" or oxidatively decay rapidly, remaining in the soil for very long periods. The more highly carbonized it is, the slower it will oxidized (e.g. at the extreme, graphite and diamond are rather inert in the soil). Slow pyrolysis biochar is recalcitrant in soils. ${ }^{100}$ High biochar doses gave initial negative 
$\mathrm{CO}_{2}$ fluxes. This is likely caused by $\mathrm{CO}_{2}$ carbonation of soluble $\mathrm{Ca}^{2+}$ and $\mathrm{Mg}^{2+}$ in the biochar to $\mathrm{CaCO}_{3}$ and $\mathrm{MgCO}_{3} \cdot{ }^{101,102}$ During incubation, a $\mathrm{CO}_{2}$ equilibrium is established between the air and water phases. Under more alkaline conditions, more $\mathrm{CO}_{2}$ dissolves in the water phase. ${ }^{103}$ Biochars from corn stover $(\mathrm{pH}$ 10.01) and rice husk ( $\mathrm{pH}$ 9.69) are highly alkaline, so both reduced $\mathrm{CO}_{2}$ emissions from the soil at all rates of biochar application. ${ }^{\mathbf{1 0 3}}$ Similarly, wood chip biochar-amended soil [at a rate of $>20 \%(\mathrm{w} / \mathrm{w})$ ] suppressed $\mathrm{CO}_{2}$ emissions versus control soil. ${ }^{104}$

\subsection{Plant responses: heights, number of leaves, total fresh and dry weights}

Biochar addition to soil increased eggplant growth and the number of leaves produced compared to the control soil. The data shown (Tables SM3 and SM4 $\uparrow$ and Fig. 9 and 10) are the mean values of the three experiments. The plant heights and numbers of leaves were measured every week on eggplants grown in CSBCand RHBC-amended soils. Using 0.5 and $1.5 \mathrm{wt} \% \mathrm{CSBC}$ had similar effects on plant growth. RHBC, used at 1.5 and $3.0 \mathrm{wt} \%$, also shows similar changes. Soils amended with $3 \%$ biochars (CSBC and RHBC) induced the largest increases in both plant height and number of leaves (see Tables SM3 and SM4 $\dagger$ ). During the $1^{\text {st }}$ to $7^{\text {th }}$ week, the increase in plant height grown in RHBC- or CSBC-amended soils was similar and significantly greater than in the control. The $3.0 \mathrm{wt} \%$ addition of CSBC stimulated more growth in plant height versus 1.5 and $0.5 \mathrm{wt} \%$ additions.

Biochar effect on plant height was measured starting from the $1^{\text {st }}$ to $7^{\text {th }}$ week. CSBC exerted significant effects on the plant height (Table SM3 $\dagger$ and Fig. 9), stimulating more growth than RHBC. Average plant height increased from $8.3 \mathrm{~cm}\left(1^{\text {st }}\right.$ week $)$ to $20 \mathrm{~cm}\left(7^{\text {th }}\right.$ week $)$ in CSBC (3.0 wt\%)-amended soil and $7.5 \mathrm{~cm}\left(1^{\mathrm{st}}\right.$ week) to $16.2 \mathrm{~cm}$ ( $7^{\text {th }}$ week) in case of RHBC (3.0 wt\%)-amended soil samples versus $6.0 \mathrm{~cm}\left(1^{\text {st }}\right.$ week) to $9.5 \mathrm{~cm}\left(7^{\text {th }}\right.$ week $)$ in case of control (Table SM3 $\dagger$ ). Thus, both CSBC and RHBC addition to soil enhanced eggplant growth versus control soil.

The number of eggplant leaves was counted from the $1^{\text {st }}$ week to $7^{\text {th }}$ week. An increase in the number of leaves occurred using both CSBC- and RHBC-amended soils (Table SM4† and

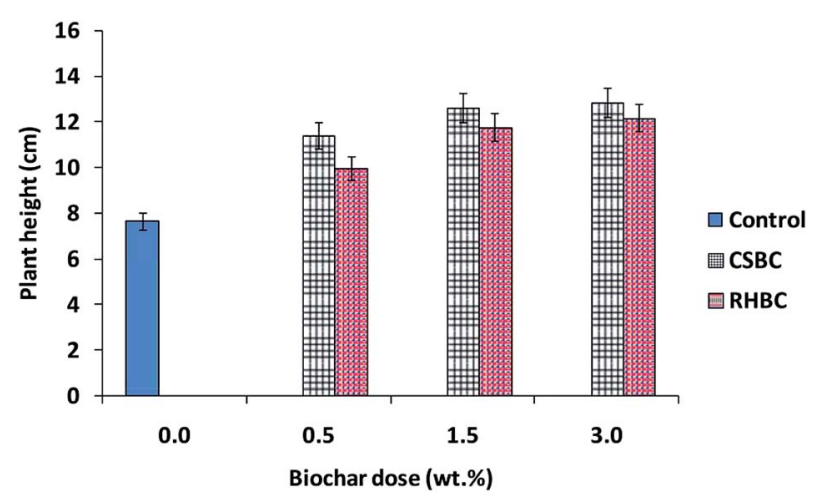

Fig. 9 Influence of CSBC and RHBC doses on plant height after an incubation period of 7 weeks. Error bars represent standard error of the mean $(n=3)$ and $p>0.05$.

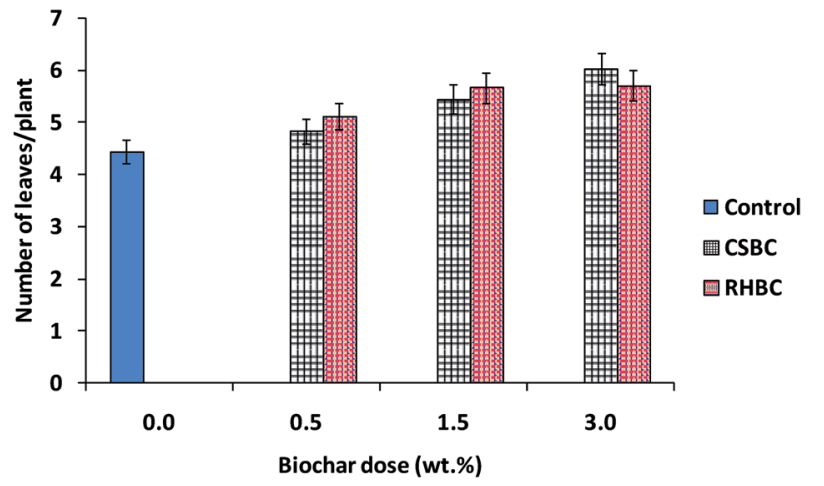

Fig. 10 Number of leaves per eggplant plant as influenced by CSBC and $\mathrm{RHBC}$ doses (\%) during an incubation period of 7 weeks. Error bars represent standard error of the mean $(n=3)$ and $p>0.05$.

Fig. 10). Both biochar-amended soils gave similar leaf growth trends.

Both biochar amendments produce incremental eggplant fresh weights as the amount of biochar added was increased [Fig. 11(A)]. Fresh weight enhancements of 42 and 39\% over that produced by control soil were achieved with CSBC (3.0 wt\%) and RHBC (3.0 wt\%) amendments.

Dry eggplant weight increased more with CSBC than RHBC amendments, exhibiting a large increment going from 1.5 to $3.0 \mathrm{wt} \%$ of CSBC [Fig. 11(B)]. Maximum dry weight increments
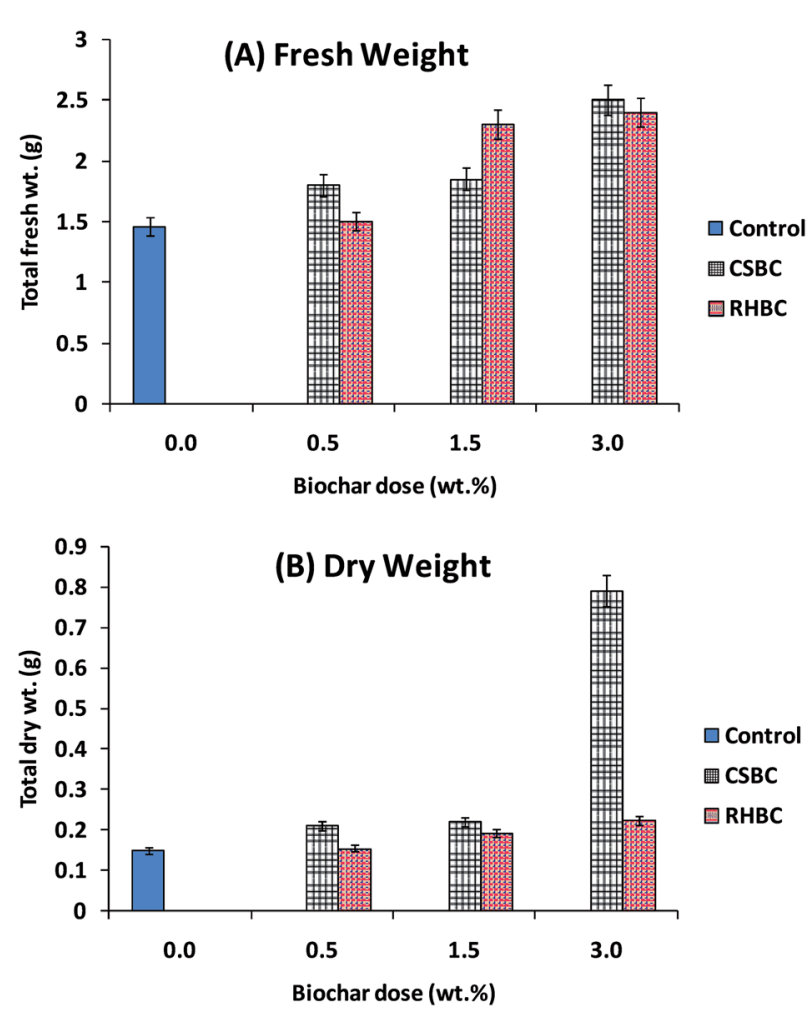

Fig. 11 Effect on (A) total fresh weight and (B) total dry weight upon biochar (CSBC and RHBC) application during an incubation period of 7 weeks. Error bars represent standard error of the mean $(n=3)$ and $p>$ 0.05 . 
of $82 \%$ versus $35 \%$ occurred in soils amended with $3.0 \%$ CSBC and $3.0 \%$ RHBC, respectively. Increased crop growth with biochar application has frequently been reported..$^{15,16,89,93,105}$ In the present study, exchangeable cation and CEC values were larger for the post-harvest soils amended with biochars (Table 2).

\subsection{Carbon mass balance}

About $3.4 \mathrm{~kg}$ of corn stover is required to make $1.0 \mathrm{~kg}$ of the slow pyrolysis (CSBC) char. Some of that carbon is lost as $\mathrm{CO}_{2}$ during pyrolysis. All the $\mathrm{C}$ in stover initially comes from the atmosphere. So, the $\mathrm{CO}_{2}$ lost during biochar formation is not considered in the overall C-budget. Table 3 summarizes the carbon mass balances. Carbon balances for adding CSBC and RHBC do clearly show a large increase in soil carbon after incubation despite experimental error and the assumptions made. The $\mathrm{CO}_{2}$ budget sample calculations for (3.0\% CSBM and $3.0 \% \mathrm{CSBC}$ ) are shown below:

3.5.1 Corn stover biomass (CSBM). Carbon in as-received soil $=1.48 \mathrm{wt} \%$

500 gram soil contains $1.48 \%$ carbon $=7.4 \mathrm{~g} \mathrm{C}$ in starting (as-received) soil

$3.0 \%$ CSBM (15 g) was added containing $44.24 \%$ carbon

Thus, total $\mathrm{C}$ in $\mathrm{CSBM}=15 \mathrm{~g} \times 0.4424=6.64 \mathrm{~g}$

Cumulative $\mathrm{CO}_{2}$ loss after 107 days incubation $=104.25 \mathrm{~g}$ $\mathrm{kg}^{-1}$ soil

Soil weight $=500 \mathrm{~g}$

Thus total carbon lost $=\left[104.25 \mathrm{~g} \mathrm{C} \mathrm{kg}^{-1}\right.$ soil $] \times(12 / 44)=$ $28.43 \mathrm{~g}$

The carbon balance can be obtained using the following expression

Carbon IN - carbon OUT $=$ carbon left in soil
Carbon $\mathrm{IN}=7.4 \mathrm{~g}$ in as received soil $+6.64 \mathrm{~g} \mathrm{C}$ added as $\mathrm{CSBM}=14.04 \mathrm{~g}$

Carbon OUT $=28.43 \mathrm{~g}$ (lost as $\left.\mathrm{CO}_{2}\right)$

Thus, carbon left in soil $=14.04-28.43=-14.40 \mathrm{~g}$

This reflects experimental error. It says (to the degree it is accurate) that significant carbon loss has occurred over the period.

3.5.2 Corn stover biochar (CSBC). Carbon in as-received soil $=1.48 \mathrm{wt} \%$ or $7.4 \mathrm{~g} \mathrm{C}$ in $500 \mathrm{~g}$ soil

$3.0 \%$ CSBC $(15 \mathrm{~g})$ was added containing $77.5 \%$ carbon

Thus, total $\mathrm{C}$ in CSBC $=15 \mathrm{~g} \times 0.775=11.63 \mathrm{~g}$

Cumulative $\mathrm{CO}_{2}$ loss after 107 days incubation $=7.45 \mathrm{~g} \mathrm{~kg}^{-1}$ soil

Soil weight $=500 \mathrm{~g}$

Thus total carbon lost $=\left[7.45 \mathrm{~g} \mathrm{C} \mathrm{kg}^{-1}\right.$ soil $] \times(12 / 44)=$ $2.03 \mathrm{~g}$

Carbon IN - carbon OUT $=$ carbon left in soil

Carbon $\mathrm{IN}=7.4 \mathrm{~g}$ in as received soil $+11.63 \mathrm{~g} \mathrm{C}$ added as $\mathrm{CSBM}=19.03$

Carbon OUT $=2.03 \mathrm{~g}\left(\right.$ lost as $\left.\mathrm{CO}_{2}\right)$

Carbon remaining in soil $=19.03-2.03=17.00 \mathrm{~g}$

Thus, there is a gain of $17.00 \mathrm{~g}$ after addition of $3.0 \%$ CSBC $\mathrm{CO}_{2}$ sequestered includes the amount of carbon in the biochar amendment which remains in the soil. One could enhance C-sequestration by charring the added biomass growth, induced by biochar amendment, and adding it to the soil.

Applying biochar removes $\mathrm{CO}_{2}$ from the air via carbon sequestered in the biochar plus any extra carbon in the incremental amount of biomass grown.

(a) Biochar $\mathrm{C}$ oxidation short term (during the year) was neglected for slow pyrolysis char made at $\sim 600{ }^{\circ} \mathrm{C}$. This should remain in the soil for decades, or centuries.

Table 3 Carbon balance with the addition of corn stover biomass, corn stover biochar, rice husk biomass and rice husk biochar

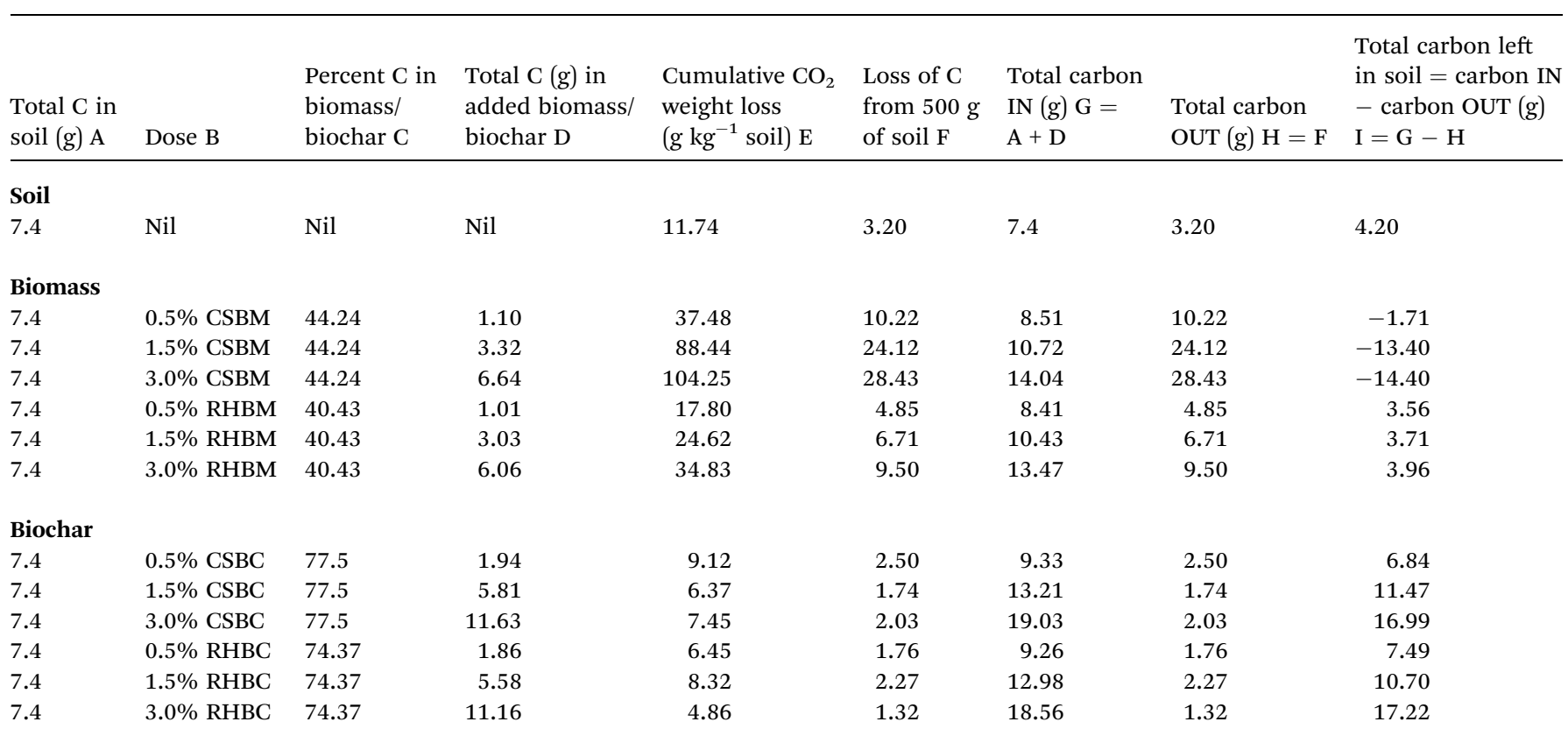


(b) It is assumed that most root mass with and without biochar present decays to $\mathrm{CO}_{2}$ rapidly (a few years).

Stover or husk biomass used as amendments, originally removed $\mathrm{CO}_{2}$ from the air. However, they decay, releasing most carbon back to the atmosphere, although some may end up in incremental plant growth biomass carbon. This mineralizes in the soil, and again converts to atmospheric carbon dioxide within a few years (Lehmann et al., 2006). Biochar, in contrast, is far more stable, remaining in soil for hundreds or thousands of years (Lehmann et al., 2006). Hence, repeated biochar applications in large scale agriculture, if applied worldwide has substantial C-sequestration potential.

\section{Conclusions}

Corn stover and rice husks were successfully converted to their slow pyrolysis biochars (CSBC and RHBC), characterized, and used in soil incubation studies. Soil amended with these biochars and both parent biomasses were incubated for 107 days. The $\mathrm{CO}_{2}$ emission from $(3.0 \% \mathrm{wt} / \mathrm{wt})$ CSBC-amended soil decreased by $15 \%$ versus control soil and by $84 \%$ compared to $3.0 \% \mathrm{wt} / \mathrm{wt}$ corn stover-amended soil. Thus, substantial $\mathrm{CO}_{2}$ emission could be avoided by first converting stover to biochar instead of directly returning the stover to agricultural fields. Additionally, biochar increases soil organic carbon, organic matter, pH, EC, cation exchanges capacity, water holding capacity. These fertility enhancements depended on the amount and type of biochar added. Biochar application increased eggplant height and leaf numbers versus control soil during incubation. Eggplants grown without adding biochar exhibited $\sim 36 \%$ of its original growth in seven weeks versus $59 \%$ in the soil amended with CSBC (3.0\% wt). Similarly, RHBCamended soil ( 0.5 and $1.5 \mathrm{wt} \%$ ) RHBC led to a $40 \%$ increase in leaf growth compared to the control soil, while $3.0 \%$ (wt/wt) RHBC gave a $53 \%$ increase.

If agricultural biomass wastes, which are currently burned in India and elsewhere, were instead pyrolyzed to reasonable biochar yields and used to amend the soil, major benefits could be realized. First, less $\mathrm{CO}_{2}$ would be emitted making biochar then by open burning of stubble and wastes. Thus, a higher fraction of the carbon in these wastes would be returned to the soil as biochar then as the ash from burning. Also, the biochar would contain the micronutrients found in ash. Since a significant portion of biochar carbon does not decay, it remains sequestered for long periods in the soil counteracting global warming. Finally, less $\mathrm{CO}_{2}$ emission from soil fertility by many known mechanisms (water retention, enhanced CEC, providing surfaces for microbes and beneficial fungi, conversion of some biochar to organic carbon, etc.) should provide a local incentive to make biochar rather than openly burn residues. These benefits need to be established in large field trails over multiyear period for specific crops. If this is demonstrated to farmers, this might reduce open burning, lower its accompanying air pollution, and emplace a carbon sequestration method in agricultural practice on a large scale, while enhancing crop yields.

\section{Conflicts of interest}

There are no conflicts of interests to declare.

\section{Acknowledgements}

Financial support [DST/IS-STAC/CO2-SR-129/12(G)] from Department of Science and Technology, New Delhi, India is thankfully acknowledged. Authors are thankful to Advance Instrumentation Research Facility (AIRF) Jawaharlal Nehru University, New Delhi for allowing us to use XRD, FTIR, SEM, TEM, and EDXRF facilities for biochar and soil characterization. We thank Dr Jeff Novak, Research Soil Scientist, USDA-ARSCPRC, 2611 West Lucas Street, Florence, SC 29501 USA for reviewing the manuscript. His suggestions improved the manuscript. We also thank Prof. Yong Sik Ok, Korea University, Seoul for his continuous help in conducting this study. Authors also thank the University Grant Commission (UGC), New Delhi for providing the financial assistance under $21^{\text {st }}$ Century IndoUS Research Initiative 2014 to Jawaharlal Nehru University, New Delhi and Mississippi State University, USA in the project "Clean Energy and Water Initiatives" [UGC No. F.194-1/ 2014(IC)]. One of the authors (DM) thanks Jawaharlal Nehru University for providing financial assistance under Second phase of University with Potential of Excellence (UPOE II) grant (ID 189). Authors also acknowledge the funding support from DST PURSE, Government of India.

\section{References}

1 S. Solomon, D. Qin, M. Manning, Z. Chen, M. Marquis, K. B. Averyt, M. Tignor and H. L. Miller, The Physical Science Basis. Contribution of Working Group I to the Fourth Assessment Report of the Intergovernmental Panel on Climate Change, Cambridge University Press, Cambridge, United Kingdom and New York, NY, USA, 2007.

2 D. M. D'Alessandro, B. Smit and J. R. Long, Angew. Chem., Int. Ed., 2010, 49, 6058-6082.

3 M. Gadalla, Ž. Olujić, M. Jobson and R. Smith, Energy Fuels, 2006, 31, 2398-2408.

4 NOAA, 2015, https://www.esrl.noaa.gov/gmd/ccgg/trends/ weekly.html.

5 USDOE, U.S. Energy Information Administration, International Energy Outlook, U.S. Department of Energy, Washington, DC, 2010.

6 P. Smith, D. Martino, Z. Cai, D. Gwary, H. Janzen, P. Kumar, B. McCarl, S. Ogle, F. O'Mara, C. Rice, B. Scholes and O. Sirotenko, in Climate Change: Mitigation. Contribution of Working Group III to the Fourth Assessment Report of the Intergovernmental Panel on Climate Change, ed. B. Metz, O. R. Davidson, P. R. Bosch, R. Dave and L. A. Meyer, Cambridge University Press, Cambridge, UK, 2007.

7 J. M. Welles, T. H. Demetriades-Shah and D. K. McDermit, Chem. Geol., 2001, 177, 3-13.

8 EPA, Climate Change, Environmental Protection Agency, January 25 2015, EPA Website, http://www.epa.gov/ climatechange/index.html. 
9 D. Woolf, J. E. Amonette, F. A. Street-Perrott, J. Lehmann and S. Joseph, Nat. Commun., 2010, 1, 56, DOI: 10.1038/ ncomms1053.

10 IPCC, in Intergovernmental Panel on Climatic Change Special Report, ed. R. T. Watson, R. Noble, B. Bolin, N. H. Ravindranath, D. J. Verardo and D. J. Dokken, Cambridge University Press, Cambridge, 2000.

11 C. Marchetti, Clim. Change, 1977, 1, 59-68.

12 D. Reichle, J. Houghton, S. Benson, J. Clarke, R. Dahlman, G. Hendrey, H. Herzog, J. Hunter-Cevera, G. Jacobs, R. Judkins, B. Kane, J. Ekmann, J. Ogden, A. Palmisano, R. Socolow, J. Stringer, T. Surles, A. Wolsky, N. Woodward and M. York, Working paper on carbon sequestration science and technology, Carbon Sequestration Research and Development, U.S. Department of Energy, Office of Science, Washington DC, DOE, 1999, https:// www.netl.doe.gov/publications/press/1999/seqrpt.pdf.

13 R. Lal, Geoderma, 2004, 123, 1-22.

14 A. Sissoko and K. Kpomblekou-A, Soil Biol. Biochem., 2010, 42, 543-550.

15 J. Lehmann, J. P. D. Silva, C. Steiner, T. Nehls, W. Zech and B. Glaser, Plant Soil, 2003, 249, 343-357.

16 B. Glaser, J. Lehmann and W. Zech, Biol. Fertil. Soils, 2002, 35, 219-230.

17 D. Mohan, C. U. Pittman Jr and P. H. Steele, Energy Fuels, 2006, 20, 848-889.

18 J. Lehmann, J. Gaunt and M. Rondon, Mitig. Adapt. Strategies Glob. Chang., 2006, 11, 403-427.

19 J. Lehmann, Front. Ecol. Environ., 2007, 5, 381-387.

20 J. Lehmann, Nat. Commun., 2007, 447, 143-144.

21 J. Lehmann, Front. Ecol. Environ., 2007, 5, 381-387.

22 M. Fowle, Biomass Bioenergy, 2007, 31, 426.

23 D. Mohan, A. Sarswat, Y. S. Ok and C. U. Pittman Jr, Bioresour. Technol., 2014, 160, 191-202.

24 M. Ahmad, A. U. Rajapaksha, J. E. Lim, M. Zhang, N. Bolan, D. Mohan, M. Vithanage, S. S. Lee and Y. S. Ok, Chemosphere, 2014, 99, 19-33.

25 D. S. Scott and J. Piskorz, Can. J. Chem. Eng., 1984, 62, 404412.

26 S. Meyer, B. Glaser and P. Quicker, Environ. Sci. Technol., 2011, 45, 9473-9483.

27 L. Li, N. Zhao, W. Wei and Y. Sun, Fuel, 2013, 108, 112-130.

28 H. W. Pennline, D. R. Luebke, K. L. Jones, C. R. Myers, B. I. Morsi, Y. J. Heintz and J. B. Ilconich, Fuel Process. Technol., 2008, 89, 897-907.

29 FONA, German Federal Ministry of Education and Research Funding Program Information Brochure, 2014.

30 J. L. Gaunt and J. Lehmann, Environ. Sci. Technol., 2008, 42, 4152-4158.

31 W. Sombroek, M. D. L. Ruivo, P. M. Fearnside, B. Glaser and J. Lehmann, Amazonian Dark Earths, 2003, pp. 125-139.

32 J. Lehmann, M. C. Rillig, J. Thies, C. A. Masiello, W. C. Hockaday and D. Crowley, Soil Biol. Biochem., 2011, 43, 1812-1836.

33 S. Jeffery, F. G. A. Verheijen, M. V. D. Velde and A. C. Bastos, Agric., Ecosyst. Environ., 2011, 144, 175-187.

34 K. A. Spokas, GCB Bioenergy, 2013, 5, 165-176.
$35 \mathrm{~J}$. Lehmann and M. Rondon, in Biological Approaches to Sustainable Soil Systems, ed. N. Uphoff, CRC Press, Boca Raton, 2005.

36 D. Busch, C. Kammann, L. Grünhage and C. Müller, J. Environ. Qual., 2012, 41, 1023-1032.

37 C. Kammann, S. Ratering, C. Eckhard and C. Müller, J. Environ. Qual., 2012, 41, 1052-1066.

38 K. Karhu, T. Mattila, I. Bergström and K. Regina, Agric., Ecosyst. Environ., 2011, 140, 309-313.

39 S. Baronti, F. P. Vaccari, F. Miglietta, C. Calzolari, E. Lugato, S. Orlandini, R. Pini, C. Zulian and L. Genesio, Eur. J. Agron., 2014, 53, 38-44.

40 W. Buss, C. Kammann and H. W. Koyro, J. Environ. Qual., 2012, 41, 1157-1165.

41 M. Rondon, J. A. Ramirez and J. Lehmann, Presented in part at the Proceedings of the 3rd USDA Symposium on Greenhouse Gases and Carbon Sequestration, Baltimore, USA, 2005.

42 Y. Yanai, K. Toyota and M. Okazaki, Soil Sci. Plant Nutr., 2007, 53, 181-188.

43 D. A. Wardle, M.-C. Nilsson and O. Zackrisson, Science, 2008, 320, 629.

44 A. Zhang, L. Cui, G. Pan, L. Li, Q. Hussain, X. Zhang, J. Zheng and D. Crowley, Effect of biochar amendment on yield and methane and nitrous oxide emissions from a rice paddy from Tai Lake plain, China, Agric., Ecosyst. Environ., 2010, 139, 469-475.

45 K. A. Spokas and D. C. Reicosky, Ann. Environ. Sci., 2009, 3, 179-193.

46 A. Hilscher, K. Heister, C. Siewert and H. Knicker, Org. Geochem., 2009, 40, 332-342.

47 K. A. Spokas, K. B. Cantrell, J. M. Novak, D. W. Archer, J. A. Ippolito, H. P. Collins, A. A. Boateng, I. M. Lima, M. C. Lamb, A. J. McAloon, R. D. Lentz and K. A. Nichols, J. Environ. Qual., 2012, 41, 973-989.

$48 \mathrm{~S}$. Wu, H. He, X. Inthapanya, C. Yang, L. Lu, G. Zeng and Z. Han, Environ. Sci. Pollut. Res., 2017, 24, 16560-16577.

49 MNRE, Ministry of New and Renewable Energy, 2009, http://mnre.gov.in/schemes/grid-connected/biomasspowercogen.

50 P. K. Gupta, S. Sahai, N. Singh, C. K. Dixit, D. P. Singh and C. Sharma, Curr. Sci., 2004, 87, 1713-1715.

51 ASTM, Standard Method for Chemical Analysis of Wood Charcoal, American Society for Testing and Materials international, West Conshohocken, PA, USA, D1762-84, 2007.

52 S. Maiti, S. Dey, S. Purakayastha and B. Ghosh, Bioresour. Technol., 2006, 97, 2065-2070.

53 R. Viji and P. P. Rajesh, J. Environ. Res. Dev., 2012, 7, 293398.

54 GOI, Soil Testing in India, Department of Agriculture and Cooperation, Ministry of Agriculture, Government of India, New Delhi, 2011.

55 J. Y. Wang, M. Zhang, Z. Q. Xiong, P. L. Liu and G. X. Pan, Biol. Fertil. Soils, 2011, 47, 887-896.

56 N. Jäger, C. F. Stange, B. Ludwig and H. Flessa, Biol. Fertil. Soils, 2011, 47, 483. 
57 R. Vijai and P. R. Prassana, J. Environ. Res. Dev., 2011, 6, 393-398.

58 MTI, Methods Manual: Soil Testing in India, Department of Agriculture \& Cooperation, Ministry of Agriculture, Government of India, New Delhi, 2011.

59 G. W. Thomas, in Methods of soil analysis, Part 2 Chemical and microbiological properties, Agronomy Monograph, ed. A. L. Page, R. H. Miller and D. R. Keeney, American Society of Agronomy, Madison, Wis, USA, 2nd edn, 1982, vol. 9, pp. 159-165.

60 P. J. Wilson, K. Thompson and J. G. Hodgson, New Phytol., 1999, 143, 155-162.

61 K. P. Upadhyay, D. George, R. S. Swift and V. Galea, J. Integr. Agric., 2014, 13, 541-546.

62 Y. Chun, G. Sheng, C. T. Chiou and B. Xing, Environ. Sci. Technol., 2004, 38, 4649-4655.

63 K. Y. Chan and Z. Xu, in Biochar for Environmental Management, ed. J. Lehmann and S. Joseph, Sterling (VA): Earthscan, 2009, pp. 67-81.

64 W. A. W. A. K. Ghani, A. Mohd, G. D. Silva, R. T. Bachmann, Y. H. Taufiq-Yap, U. Rashid and A. A. H. Al-Muhtaseb, Ind. Crops Prod., 2013, 44, 18-24.

65 B. L. Chen, D. D. Zhou and L. Z. Zhu, Environ. Sci. Technol., 2008, 42, 5137-5143.

66 T. A. J. Kuhlbusch, Environ. Sci. Technol., 1995, 29, 26952702.

67 M. Uchimiya, L. H. Wartelle, K. T. Klasson, C. A. Fortier and I. M. Lima, J. Agric. Food Chem., 2011, 59, 2501-2510.

68 Z. Liu, F. S. Zhang and J. Wu, Fuel, 2010, 89, 510-514.

69 B. Chen and Z. Chen, Chemosphere, 2009, 76, 127-133.

70 X. D. Cao and W. Harris, Bioresour. Technol., 2010, 101, 5222-5228.

71 A. L. Biederman and W. S. Harpole, GCB Bioenergy, 2013, 5, 202-214.

72 Y. Huang, X. Yin, C. Wu, C. Wang, J. Xie, Z. Zhou, L. Ma and H. Li, Biotechnol. Adv., 2009, 27, 568-572.

73 T. Chen, R. Liu and N. R. Scott, Fuel Process. Technol., 2016, 142, 124-134.

74 X. Xu, X. Hu, Z. Ding and Y. Chen, Chemosphere, 2017, 189, 76-85.

75 J. A. Madrid and M. Lanzón, Appl. Surf. Sci., 2017, 424, 2-8.

76 X. Ma, S. Yuan, L. Yang, L. Li, X. Zhang, C. Su and K. Wang, CrystEngComm, 2013, 15, 8288-8299.

77 C. Jin, L.-N. Jin, M.-X. Guo, P. Liu and S.-W. Bian, J. Colloid Interface Sci., 2017, 508, 426-434.

78 F. R. Shamskar, F. Meshkani and M. Rezaei, J. CO2 Util., 2017, 22, 124-134.

79 X. Li, Q. Zhang, B. Hou, J. Ye and X. Li, Powder Technol., 2017, 318, 224-229.

80 C. H. Chia, B. Gong, S. D. Joseph, C. E. Marjo and A. M. Rich, Vib. Spectrosc., 2012, 62, 248-257.

81 R. S. Kumar and P. Rajkumar, Infrared Phys. Technol., 2014, 67, 30-41.

82 E. Smidt and M. Schwanninger, Spectrosc. Lett., 2005, 38, 247-270.
83 D. Mohan, H. Kumar, A. Sarswat, M. Alexandre-Franco and C. U. Pittman Jr, Chem. Eng. J., 2014, 236, 513-528.

84 D. Mohan, P. Singh, A. Sarswat, P. H. Steele and C. U. Pittman, J. Colloid Interface Sci., 2015, 448, 238-250.

85 D. Naumann, P. C. Schultz and D. Helm, in Infrared Spectroscopy of Biomolecules, ed. H. H. Mantsch and H. H. Chapmanx, Wiley, New York, USA, 1996, p. 279.

86 F. B. Reig, J. V. G. Adelantado and M. C. M. M. Moreno, Talanta, 2002, 58, 811-821.

87 B. Smith, Infrared Spectral Interpretation, CRC Press, Boca Raton, FL, 1999.

88 L. V. Zwieten, S. Kimber, S. Morris, A. Downie, E. Berger, J. Rust and C. Scheer, Soil Res., 2010, 48, 555-568.

89 K. Y. Chan, L. V. Zwieten, I. Meszaros, A. Downie and S. Joseph, Aust. J. Soil Res., 2007, 45, 629-634.

90 A. Nigussie, E. Kissi, M. Misganaw and G. Ambaw, Am.Eurasian J. Agric. Environ. Sci., 2012, 12, 369-376.

91 K. Y. Chan, L. V. Zwieten, I. Meszaros, A. Downie and S. Joseph, Soil Res., 2008, 46, 437-444.

92 F. Verheijen, S. Jeffery, A. C. Bastos, M. V. D. Velde and I. Diafas, Biochar Application to Soils : A Critical Scientific Review of Effects on Soil Properties, Processes and Functions, European Commission, Joint Research Centre, Institute for Environment and Sustainability, 2010.

93 M. A. Rondon, J. Lehmann, J. Ramírez and M. Hurtado, Biol. Fertil. Soils, 2007, 43, 699-708.

94 J. W. Lee, M. Kidder, B. R. Evans, S. Paik, A. C. Buchanan, C. T. Garten and R. C. Brown, Environ. Sci. Technol., 2010, 44, 7970-7974.

95 T. M. Abdel-Fattah, M. E. Mahmoud, S. B. Ahmed, M. D. Huff, J. W. Lee and S. Kumar, J. Ind. Eng. Chem., 2015, 22, 103-109.

96 S. Prabha, R. Renuka, N. P. Sreekanth, P. Babu and A. P. Thomas, Ann. Environ. Sci., 2013, 7, 17-30.

97 S. Schimmelpfenning and B. Glaser, J. Environ. Qual., 2007, 41, 1001-1013.

98 S. L. Martin, M. L. Clarke, M. Othman, S. J. Ramsden and H. M. West, Biomass Bioenergy, 2015, 79, 39-49.

99 D. L. Jones, D. V. Murphy, M. Khalid, W. Ahmad, G. Edwards-Jones and T. H. DeLuca, Soil Biol. Biochem., 2011, 43, 1723-1731.

100 K. Wiedner, C. Rumpel, C. Steiner, A. Pozzi, R. Maas and B. Glaser, Biomass Bioenergy, 2013, 59, 264-278.

101 S.-S. Lim, W.-J. Choi, K.-S. Lee and H.-M. Ro, J. Soils Sediments, 2012, 12, 1299-1308.

102 K. E. A. Ohlsson, Soil Sci. Soc. Am. J., 2000, 64, 2155-2161. 103 Y. Liu, M. Yang, Y. Wu, H. Wang, Y. Chen and W. Wu, J. Soils Sediments, 2011, 11, 930-939.

104 K. A. Spokas, J. M. Baker and D. C. Reicosky, Plant Soil, 2010, 333, 443-452.

105 H. Asai, B. K. Samson, H. M. Stephan, K. Songyikhangsuthor, K. Homma, Y. Kiyono, Y. Inoue, T. Shiraiwa and T. Horie, Field Crops Res., 2009, 111, 81-84. 